\title{
AIRBORNE GRAVITY GRADIOMETRY SURVEY IN THE SOUTHEASTERN PORTION OF PIMENTA BUENO GRABEN IN PARECIS BASIN: INTEGRATED 2D FORWARD MODELING AND ITS IMPLICATIONS IN DEFINING A NEW STRUCTURAL FRAMEWORK
}

\author{
Alan de Souza Cunha ${ }^{1}$, Fábio Andre Perosi², Luiz Fernando Braga ${ }^{3}$, Leandro Barros Adriano ${ }^{4}$, \\ Marlon Cabrera Hidalgo-Gato ${ }^{4}$, Victor Pereira do Couto ${ }^{5}$ and Daniel Santos da Silva ${ }^{4}$
}

\begin{abstract}
Airborne geophysical surveys are widely used in geological prospecting of hydrocarbon reservoirs. The efficiency and acquisition speed of these methods in covering large areas accredit them as a key tool for any exploration project where there are sparse technical data available to support the exploratory decisions. Among the airborne geophysical methods, potential methods, namely, gravity and magnetics are the most spread in oil \& gas projects of this nature. Such methods are used to support the generation of regional geological knowledge and also in detailed approaches, integrated with seismic, geochemical and well data. The objectives of this work were to describe the Falcon ${ }^{\mathrm{TM}}$ Airborne Gravity Gradiometry System, explaining acquisition and processing steps, and crosscheck the results of its application in the southeastern portion of the Parecis Basin with two proposed models for the structural genesis and evolution proposed by the academy. Throughout the integration of the airborne gravity gradiometry and magnetic data along 2D seismic section it was possible to infer the geometry of the Pimenta Bueno Graben. While many works have mapped basement depth about 7,000 m, the current modeling shows basement deeper than 10,000 $\mathrm{m}$.
\end{abstract}

Keywords: airborne gravity gradiometry, 2D forward modeling, Parecis Basin, Falcon ${ }^{\mathrm{TM}}$, tectonic framework.

RESUMO. Levantamentos aerogeofísicos são amplamente utilizados na prospecção geológica de reservatórios de hidrocarbonetos. A eficiência e a velocidade de aquisição desses métodos na cobertura de grandes áreas os credenciam como uma ferramenta fundamental para qualquer projeto de exploração onde há poucos dados técnicos disponíveis para apoiar as decisões exploratórias. Dentre os métodos geofísicos aéreos, os potenciais gravimétricos e magnetométricos são os mais utilizados em projetos da natureza de prospecção de óleo e gás. Tais métodos são utilizados para apoiar a geração de conhecimento geológico regional e também em abordagens de detalhe, integrados com seções sísmicas, dados geoquímicos e de poço. Este trabalho pretende apresentar o Sistema Falcon ${ }^{\top M}$ de Gravimetria Gradiométrica, descrevendo suas etapas de aquisição e processamento, e interpretação dos resultados de sua aplicação na porção sudeste da Bacia do Parecis, em confronto com dois modelos propostos para a gênese e evolução estrutural da Bacia. Através da integração dos dados de gravimetria gradiométrica com dados magnéticos extraídos ao longo da secção sísmica 2D foi possível inferir a geometria detalhada do graben de Pimenta Bueno. Enquanto trabalhos anteriores mapearam a profundidade do embasamento em cerca de 7.000 metros, uma modelagem 2D direta e vinculada mostra que o mesmo pode alcançar, de forma localizada, profundidades maiores que 10.000 metros.

Palavras-chave: gravimetria gradiométrica aérea, modelagem direta 2D, Bacia dos Parecis, Falcon ${ }^{\mathrm{TM}}$, arcabouço tectônico.

\footnotetext{
1CGG-UFRJ, Av. Presidente Wilson, 231, salas 1703-1704, Centro, 20030-021 Rio de Janeiro, RJ, Brazil. Phone: +55(21) 98318-0766-E-mail: alan.cunha@cgg.com 2UFRJ, Av. Athos da Silveira, 274 (prédio CCMN), bloco G, Campus Ilha do Fundão (Cidade Universitária), 21949-900 Rio de Janeiro, RJ, Brazil. Phone: +55(21) 99337-6960 - E-mail: faperosi@geologia.ufrj.br

3 Independent Consultant, Rio de Janeiro, RJ, Brazil. Phone: +1 281739-0000 - E-mail: Ibsantanabraga@gmail.com

${ }^{4}$ CGG Multi-Physics, Av. Ayrton Senna, 2541, Rua F1, Lt 47, Aeroporto de Jacarepaguá, Barra da Tijuca, 22775-002 Rio de Janeiro, RJ, Brazil. Phone: +55(21) 35017700 - E-mails: leandro.adriano@cgg.com; marlon.cabrera@cgg.com; daniel.silva2@cgg.com

5 Observatório Nacional, Rio de Janeiro, RJ, Brazil - E-mail: victordocouto@gmail.com
} 


\section{INTRODUCTION}

The Parecis Basin is still a matter of debate among geoscientists. The scarcity of studies and available data are still a difficulty for the understanding of the genesis and its sedimentary evolution. In 2012, LASA performed an airborne FALCON ${ }^{\mathrm{TM}}$ survey in the southern portion of the Parecis Basin (Fig. 1), being the first time that this basin was covered with a high resolution geophysical survey. The surveyed block has approximately $17,000 \mathrm{~km}^{2}$ flown by $37,577.6$ kilometers of gravity gradiometry and magnetic profiles. This survey was designed with 500 meters spacing for flight lines and 10,000 meters spacing for tie lines acquired at 700 meters barometric altitude.

According to Almeida (1983), the Parecis Basin is one of the largest Brazilian Intracratonic basins, covering approximately $500,000 \mathrm{~km}^{2}$ in the Brazilian Amazon area (see inset in Fig. 1). Siqueira \& Teixeira (1993) divided this basin, from west to east, in the Rondônia, Juruena and Alto Xingu sub-basins, separated by the Vilhena and Serra Formosa Magmatic Arcs. This division was based on geophysical and geologic data: The extreme west is the Rondônia tectonic depression, the central portion is a gravity low and the eastern part is the Alto Xingu Basin. The main structural trend is oriented E-W and suggests the continuation, under the Mesozoic Sequence, of the Pimenta Bueno and Colorado Grabens (Fig. 2).

The study area (solid line red polygon in Fig. 2) is located in the extreme southeastern portion of the Pimenta Bueno Graben. This is the major feature of the Parecis Basin located between the "Alto de Braznorte" (Braznorte High) and the "Alto do Rio Branco" (Rio Branco High).

Bahia (2007) considers that the sedimentary evolution of the Parecis Basin is associated to extensional events that occurred in the Ordovician, followed by sedimentation lasting up to the Permian (Cacoal, Furnas, Ponta Grossa and Fazenda da Casa Branca formations). Throughout the Mesozoic other sedimentary events were responsible for the deposition of the Anari, Rio Ávila, Salto das Nuvens and Utiariti formations.

Braga \& Siqueira (1995) concluded that the sedimentary infill of the Pimenta Bueno Graben is the thickest one in the entire Parecis Basin. The well named "Salto Magessi" (2-SM-1-MT), drilled by Petrobras in 1995, reveals $5.779 \mathrm{~m}$ of sediments without any presence of volcanic rocks.

According to P. Zalán (2013; oral communication), the Parecis Basin should be classified as a Proterozoic Basin. This was corroborated by the interpretation of the last seismic lines acquired by ANP published in technical seminar of the $12^{\text {th }}$ Bid Round (Haeser, 2013). In this seminar, ANP presented a new stratigraphic chart (Fig. 3) for the basin that shows wide Proterozoic sequences, sparsely and discordantly covered by very thin Paleozoic and Mesozoic sequences. The seismic surveys showed a thick sedimentary sequence filling deep grabens oriented along NW-SE. The geometry of these grabens shows compressional structures that could have been generated by the collision of the Paraguay-Araguaia Belt in its southern flank, suggesting a collisional event younger than the supposed E-W-trending taphrogenic event, during which the Paraguay belt was thrust over the Proterozoic sedimentary sequences causing the southern flank subsidence due to loading effect, in a classical foreland tectonic scheme.

In this paper we interpret airborne magnetic and gravity data of the Parecis Basin proposing the basement relief along the seismic line L0295-0010, located along the Pimenta Bueno Graben. It was also possible to define at least four geological provinces according to the potential fields data. A 2D Seismic line and a well log (Salto Magessi well) were also used as constrains for all the results.

\section{The FALCON ${ }^{T M}$ System - A brief system description}

The Falcon ${ }^{\mathrm{TM}}$ system is composed by a gradiometer that has a wheel on which are installed two complements of four accelerometers, A and B (Fig. 4). The gradient of the gravity field is measured by the difference of the two pairs oppositely positioned in the rotating wheel. The key factor of the Falcon ${ }^{T \mathrm{M}}$ system is that the accelerometers measure with continuous repeatability, in other words, each sample has two independent measures that will be used for quality control.

The system adopts a North, East, and Down coordinate sign convention and these directions (N, E, and D) are used as subscripts to identify the gravity gradient tensor components (gravity vector derivatives). Lower case is used to identify the components of the gravity field and upper case to identify the gravity gradient tensor components. Thus the parameter usually measured in a normal exploration ground gravity survey is gD and the vertical gradient of this component is GDD. The vertical component of gravity $(\mathrm{gD})$ is delivered in the usual units of $\mathrm{mGal}$. The gradient tensor components are delivered in eotvos, which is usually abbreviated to "E". By definition $1 \mathrm{E}=10^{-4} \mathrm{mGal} / \mathrm{m}$ (Dransfield \& Zeng, 2009).

In standard ground gravity surveys, the component measured is " $\mathrm{gD}$ ", which is the vertical component of the acceleration due to gravity. In airborne gravity systems, since the aircraft is itself accelerating, measurement of "gD" cannot be made to the same precision and accuracy as on the ground (Boggs \& Dransfield, 


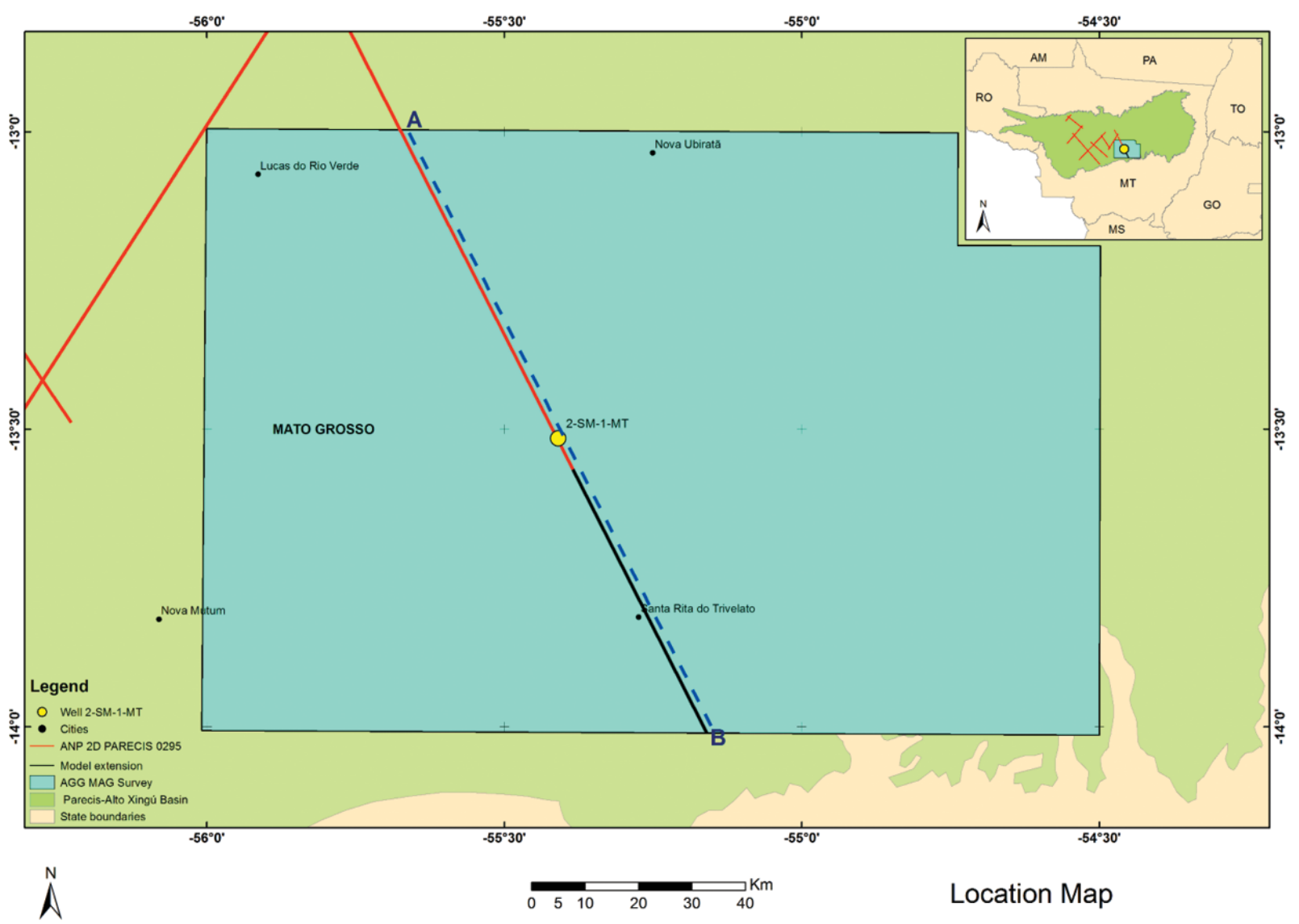

Figure 1 - Location map of the survey.

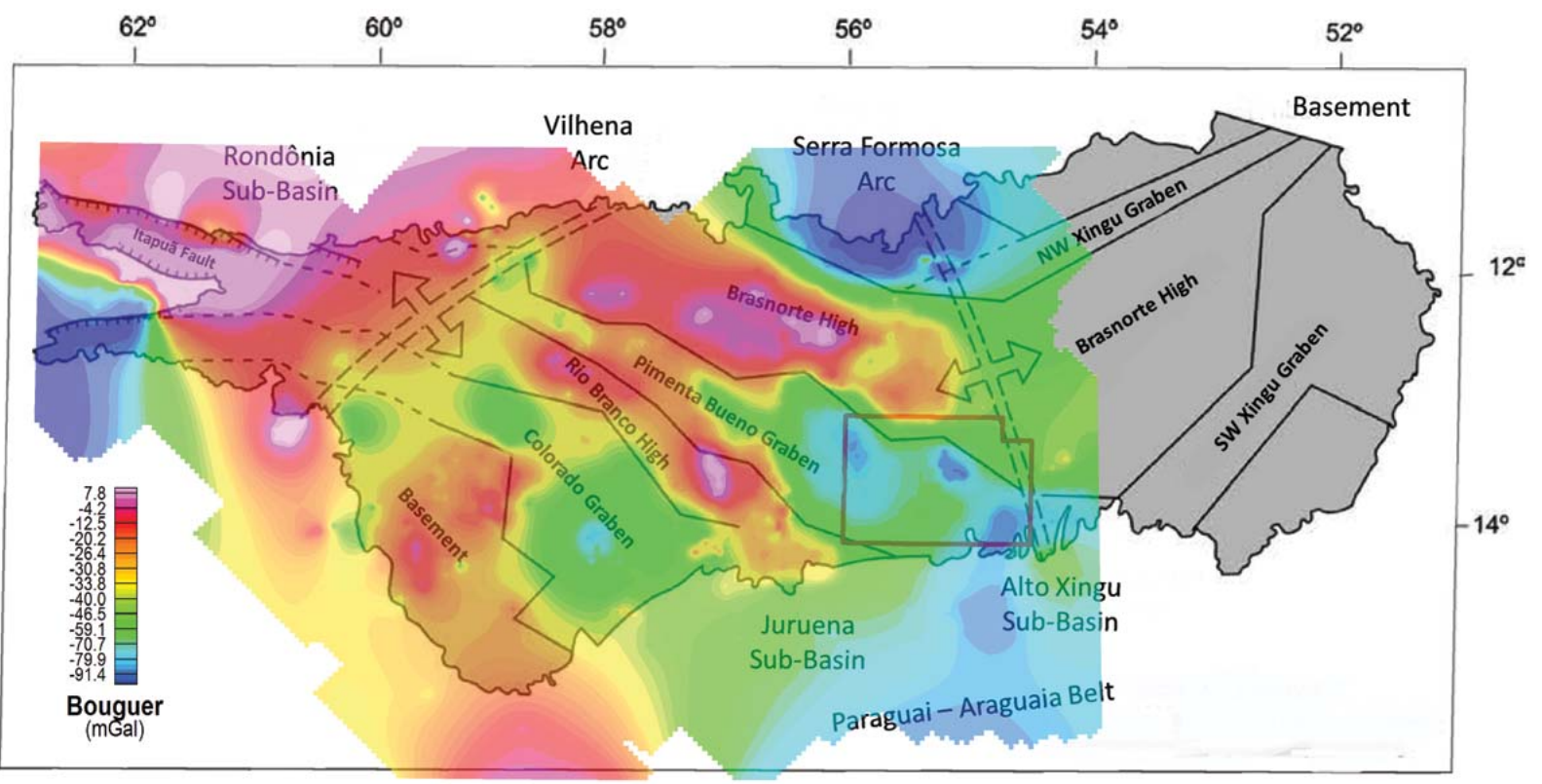

Figure 2 - Location of the study area (red polygon) in the tectonic map of the Parecis Basin (modified from Bahia, 2007). 


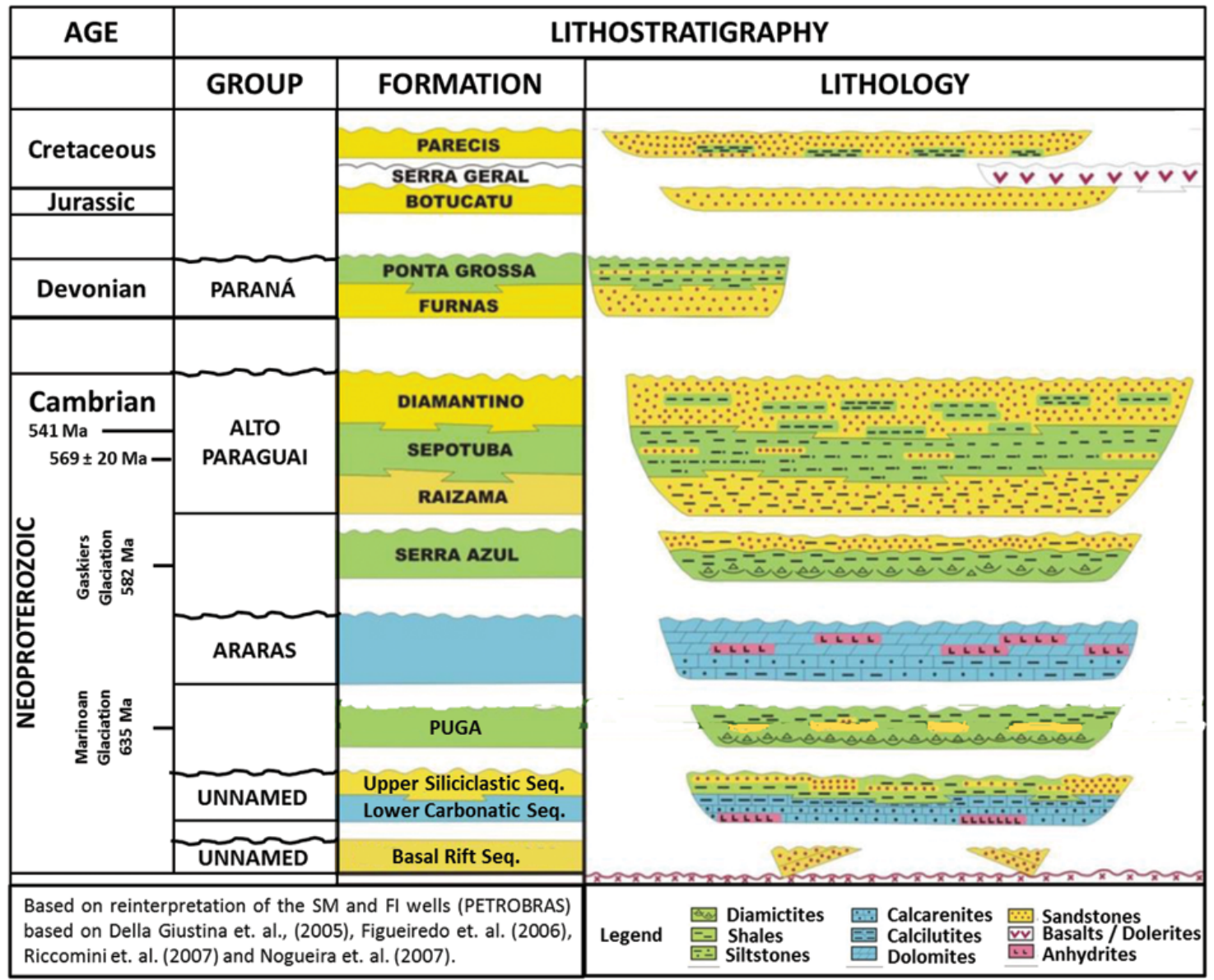

Figure 3 - New stratigraphic chart of the Parecis Basin (modified from Haeser, 2013)

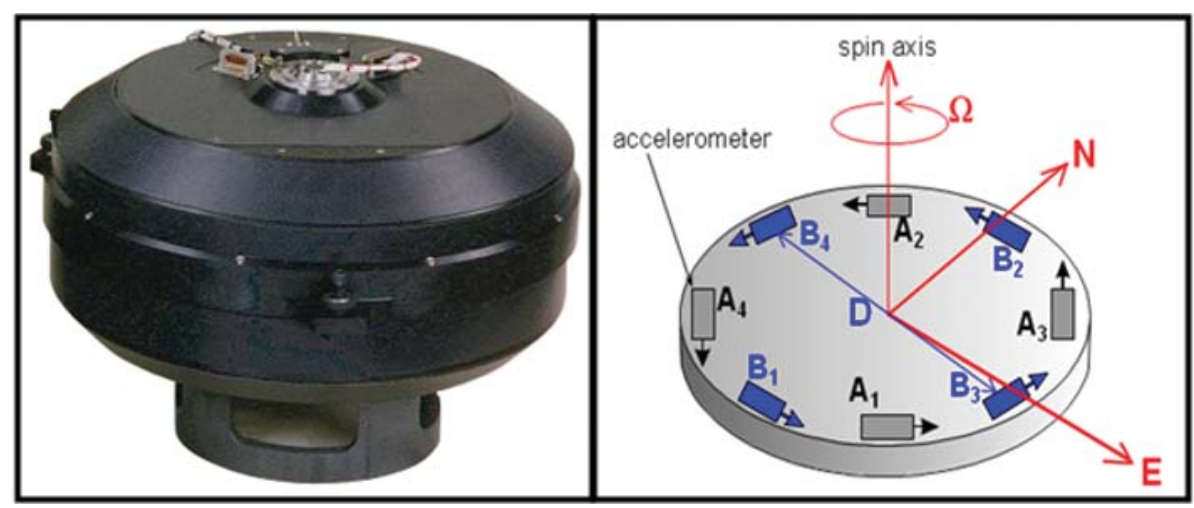

Figure 4 - Gravity Gradiometry Instrument.

2004). Airborne gravity gradiometry uses a differential measurement to remove the aircraft motion effects and delivers gravity data of a spatial resolution and sensitivity comparable with ground gravity data. The FALCON ${ }^{\mathrm{TM}}$ gradiometer instrument acquires two curvature components of the gravity gradient tensor namely GNE and GUV where GUV $=($ GEE - GNN)/2 (Lee, 2001).
Since these curvature components cannot easily and intuitively be related to the causative geology, they are transformed into the vertical gravity gradient (GDD), and integrated to derive the vertical component of gravity $(\mathrm{gD})$. Interpreters display, interpret and model both GDD and gD. The directly measured GNE and GUV data are appropriate for use in inversion software to 


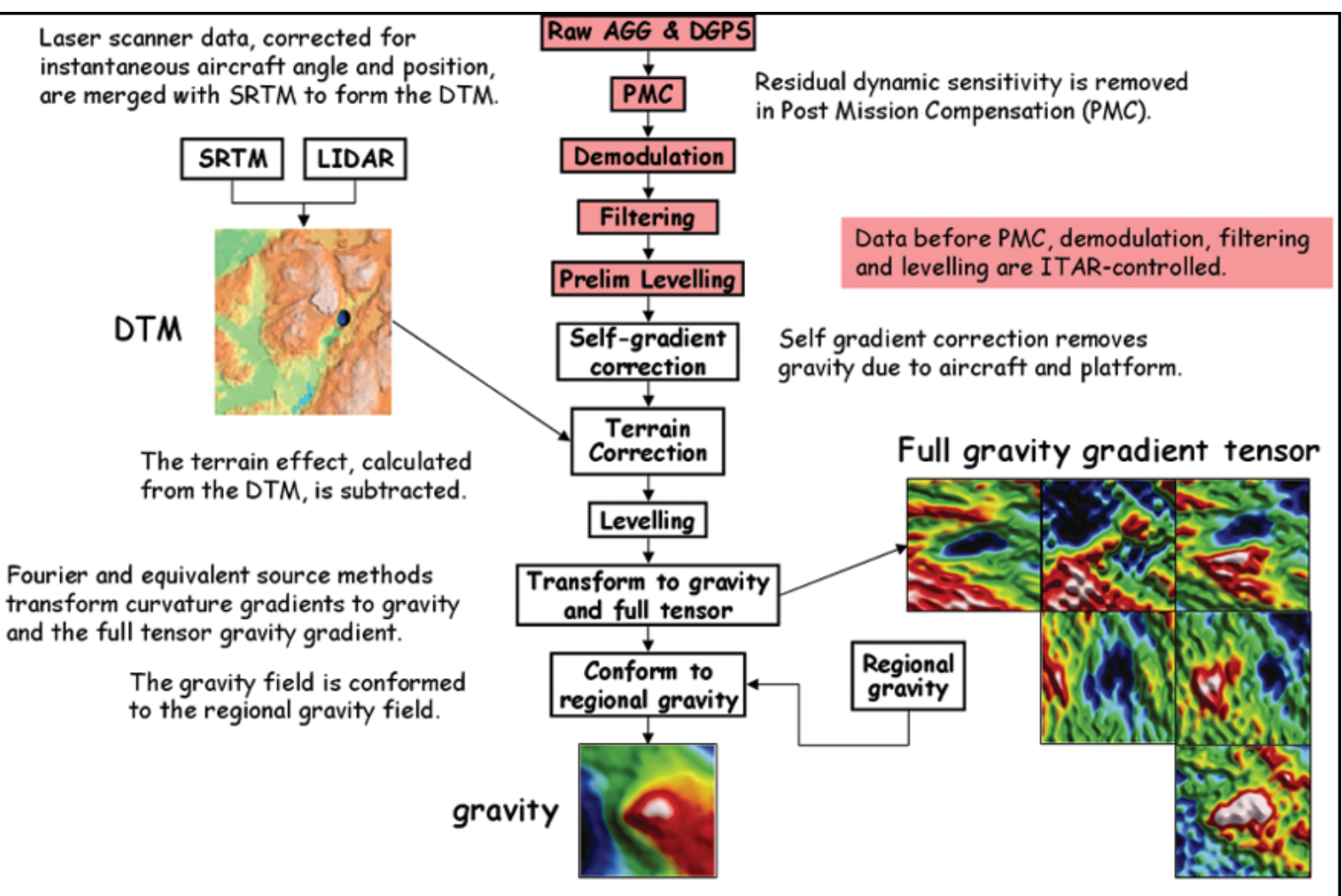

Figure $\mathbf{5}$ - Workflow chart of the main processing steps of FALCON'M . The AGG raw data have restricted access by International Traffic Arms Regulation (ITAR) - US Department of State (Dransfield \& Lee, 2004).

generate density models of the Earth. The vertical gravity gradient, GDD, is more sensitive to small or shallow sources and has greater spatial resolution than $\mathrm{gD}$ (similar to the way that the vertical magnetic gradient provides greater spatial resolution and increased sensitivity to shallow sources of the magnetic field). In the integration of GDD to give gD, the very long wavelength component, (wavelengths comparable to or greater than the size of the survey area), cannot be fully recovered. Long wavelength gravity was therefore incorporated in the $\mathrm{gD}$ data from other sources that was is meant by conformed Gravity in the literature (Dransfield, 2010). The Danish National Space Centre global gravity data of 2008 (DNSC08) was used as for producing the conformed gD grid. Figure 5 shows the processing workflow of FALCON ${ }^{\mathrm{TM}}$ data.

With all the FALCON ${ }^{\mathrm{TM}}$ AGG instruments, there are two measurements made of both the NE and UV curvature components during acquisition. This gives a pair of independent readings at each sample point. The standard deviation of half the difference between these pairs is a good estimate of the survey noise. This is calculated for each line, and the average of all the survey lines is the figure quoted for the survey as a whole. This difference error has been demonstrated to follow a 'normal' or Gaussian statistical distribution, with a mean of zero. Therefore, the bulk of the population (95\%) will lie between $-2 \sigma$ and $+2 \sigma$ of the mean. For a typical survey noise estimate of, say, $3 \mathrm{E}, 95 \%$ of the noise will be between $-6 \mathrm{E}$ and $+6 \mathrm{E}$. These typical errors in the curvature gradients translate to errors in GDD of about $5 \mathrm{E}$ and in $\mathrm{gD}$ (in the shorter wavelengths) in the order of $0.1 \mathrm{mGal}$ (Lee et al., 2001).

\section{Gravity, Gravity Gradiometry and Magnetic Enhancements}

The survey herein mentioned also contain magnetic data. Actually, any Falcon ${ }^{T M}$ gravity gradiometry survey has both data content, magnetic and gravity gradiometry data. The interpretation workflow used in this study considers the use of various filters applied to the basic datasets: total magnetic intensity corrected from IGRF and reduced to pole (Fig. 6), conformed gD terrain corrected (Fig. 7), aiming to base the qualitative interpretation of tectonic structures and igneous features within the area of interest. 


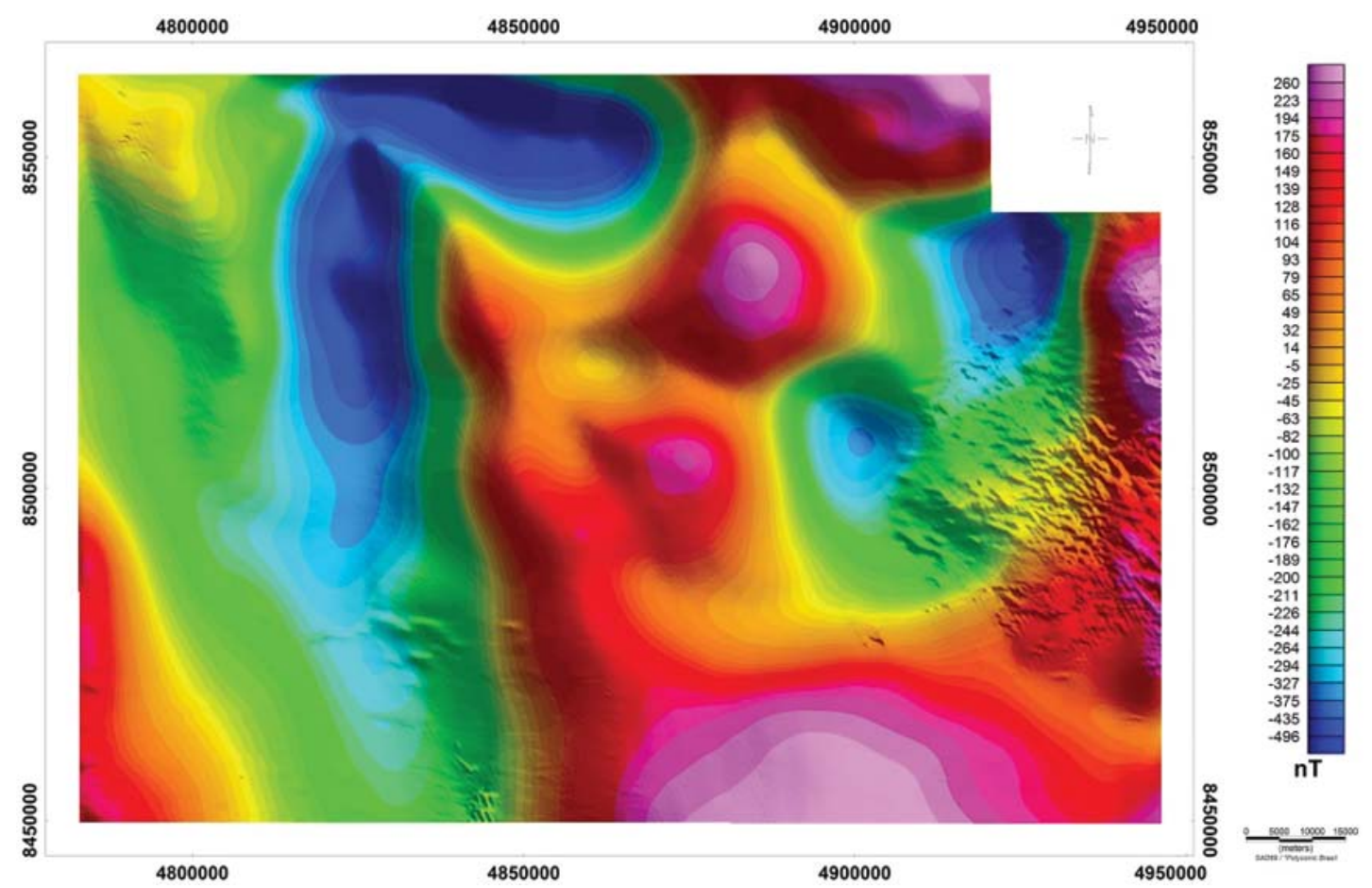

Figure $\mathbf{6}$ - Total Magnetic Intensity, IGRF removed and reduced to pole.

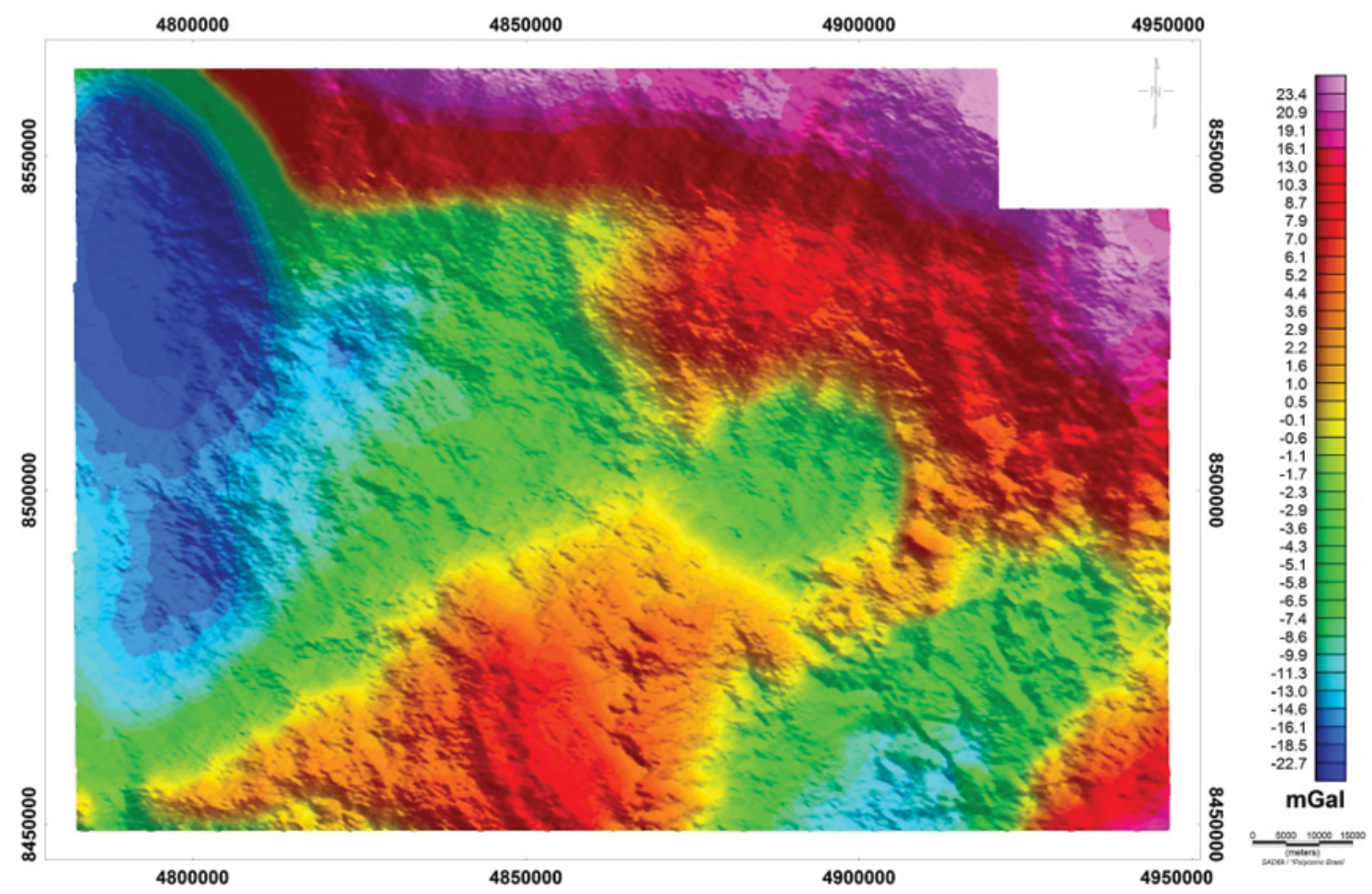

Figure 7 - Conformed gD - Terrain correction $2.5 \mathrm{~g} / \mathrm{cm}^{3}$. 


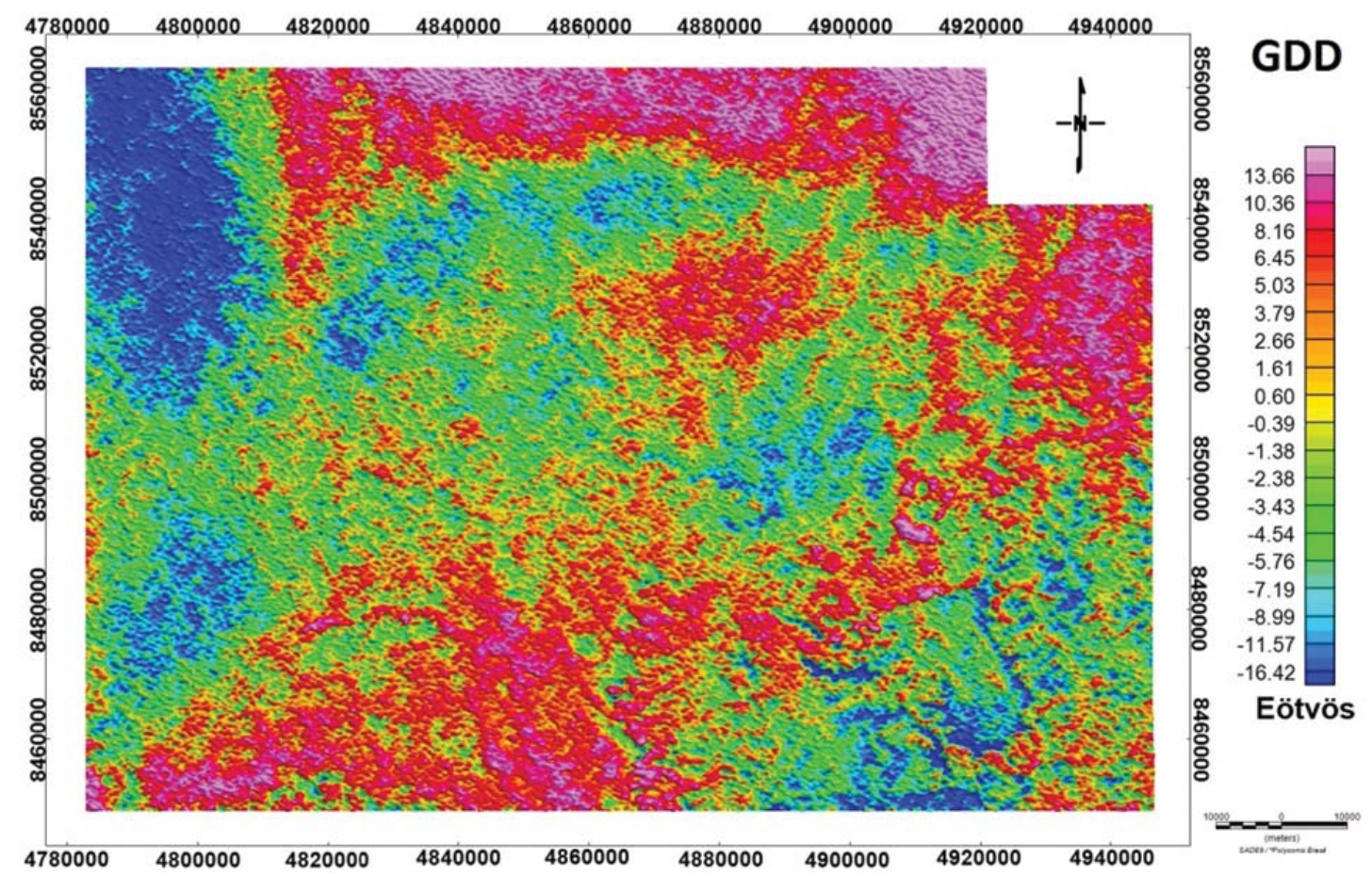

Figure 8 - GDD - Vertical tensor.

This work generated the following products: First and second vertical derivative, tilt angle, horizontal gradient for the magnetic dataset. For the gravity gradiometric dataset, the GDD represents the first vertical derivative (Fig. 8), beyond this, horizontal gradient and high pass filter with cut off of $35 \mathrm{~km}$ full wave length were generated (Fig. 9).

In order to evaluate results of specific filtering for Gravity Gradient data there are important properties which enable product generation for supporting the interpretation. The complete gradient tensor $\Gamma$ is defined by the matrix below. Note that the symmetry between tensors components obligates $G i j$ be equals $G j i$ and the matrix trace is given by Eq. (2). Since the region is free-source, the tensors satisfies Laplace's equation and the trace is equal to zero $(\operatorname{Trace}(\Gamma)=0 ; \operatorname{Gdd}=-$ Gee $-\mathrm{Gnn})$. Then we have five independent tensors where $\Gamma i j^{\text {th }}$ designates the $i j^{\text {th }}$ element of the matrix below:

$$
\begin{aligned}
& \text { Gee Gen Ged } \\
& \Gamma=\text { Gne Gnn Gnd } \\
& \text { Gde Gdn Gdd } \\
& \operatorname{Trace}(\Gamma)=\sum_{i=1}^{3} G i i=G e e+G n n+G d d
\end{aligned}
$$

There are three invariants for the coordinate transformation and they are described by the following equations (Dickinson et al., 2009).

$$
\begin{aligned}
I_{0}= & \operatorname{Trace}(\Gamma)=0 \\
I_{1}= & G e e * G n n+G n n * G d d \\
& +G e e * G d d-G e n^{2}-G n d^{2}-G e d^{2} \\
I_{2}= & \operatorname{det}(\Gamma)=G e e *\left(G n n * G d d-G n d^{2}\right) \\
& +G e n *(G n d * G e d-G e n * G d d) \\
& +G e d *(G e n * G n d-G e d * G n n)
\end{aligned}
$$

The invariants operations $I_{1}$ and $I_{2}$ can be used as an interpretation tool because they are supposed to emphasize large volumetric bodies (Figs. 10, 11 and 12) while $I_{0}$ could represent an additional tool for monitoring the noise content in the data, since it must be ideally null (or close to zero for real surveys were is impossible to achieve zero noise). It is important to know the invariant can not replace the field component analysis but is a good qualitative complement for the interpretation maps.

\section{Spatial distribution of Igneous Rock}

Aiming to map the spatial distribution of the igneous rocks and identify main intra-sedimentary igneous features over the survey area, many filters were applied to both Magnetic and Gravity Gradient dataset. The filters formerly applied does not seem to contribute significantly to the problem of enhancing the gravity 


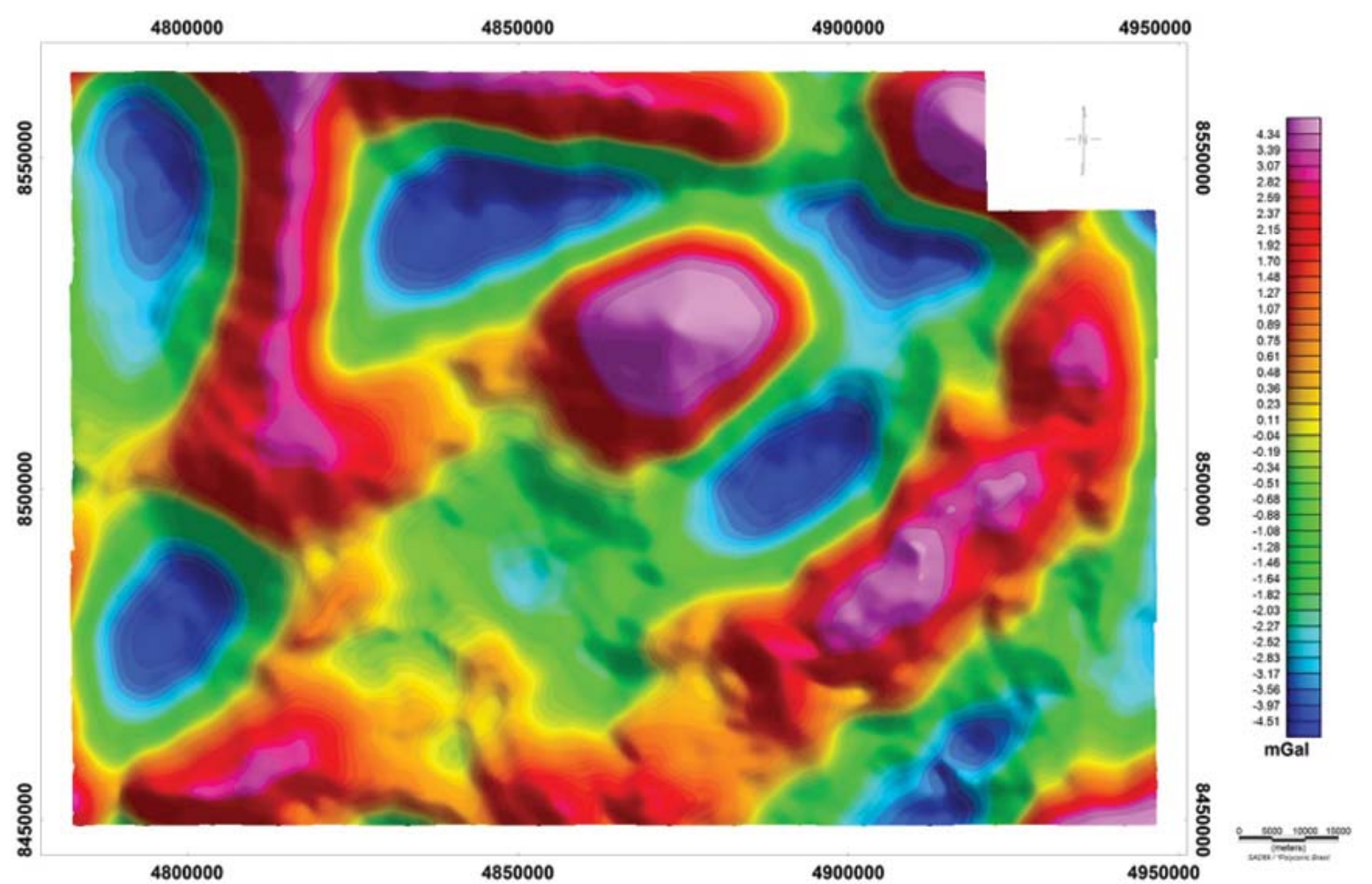

Figure $\mathbf{9}$ - High pass filter over conformed gD with cut off $<60 \mathrm{~km}$.
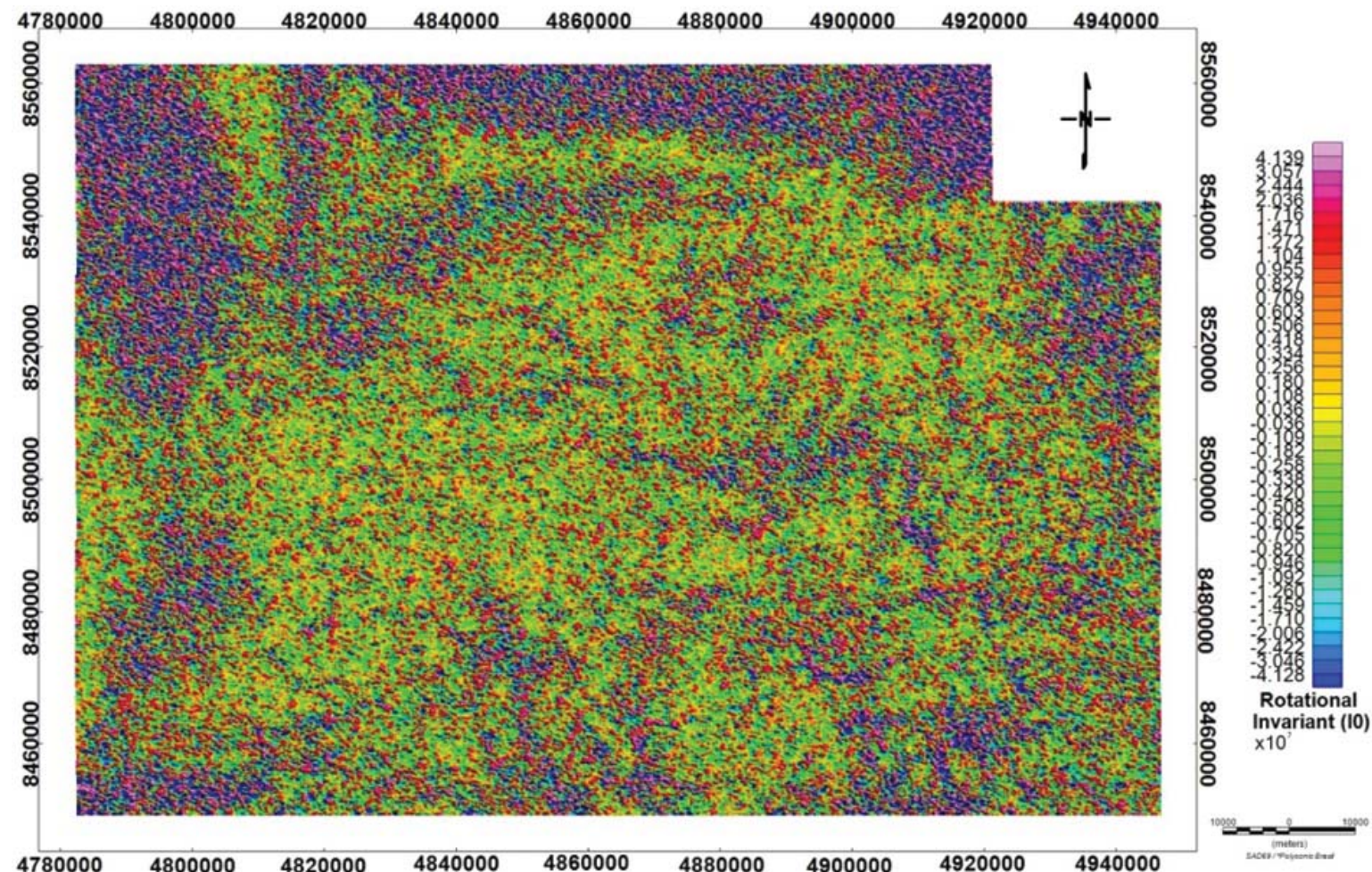

Figure 10 - Invariant 0. 

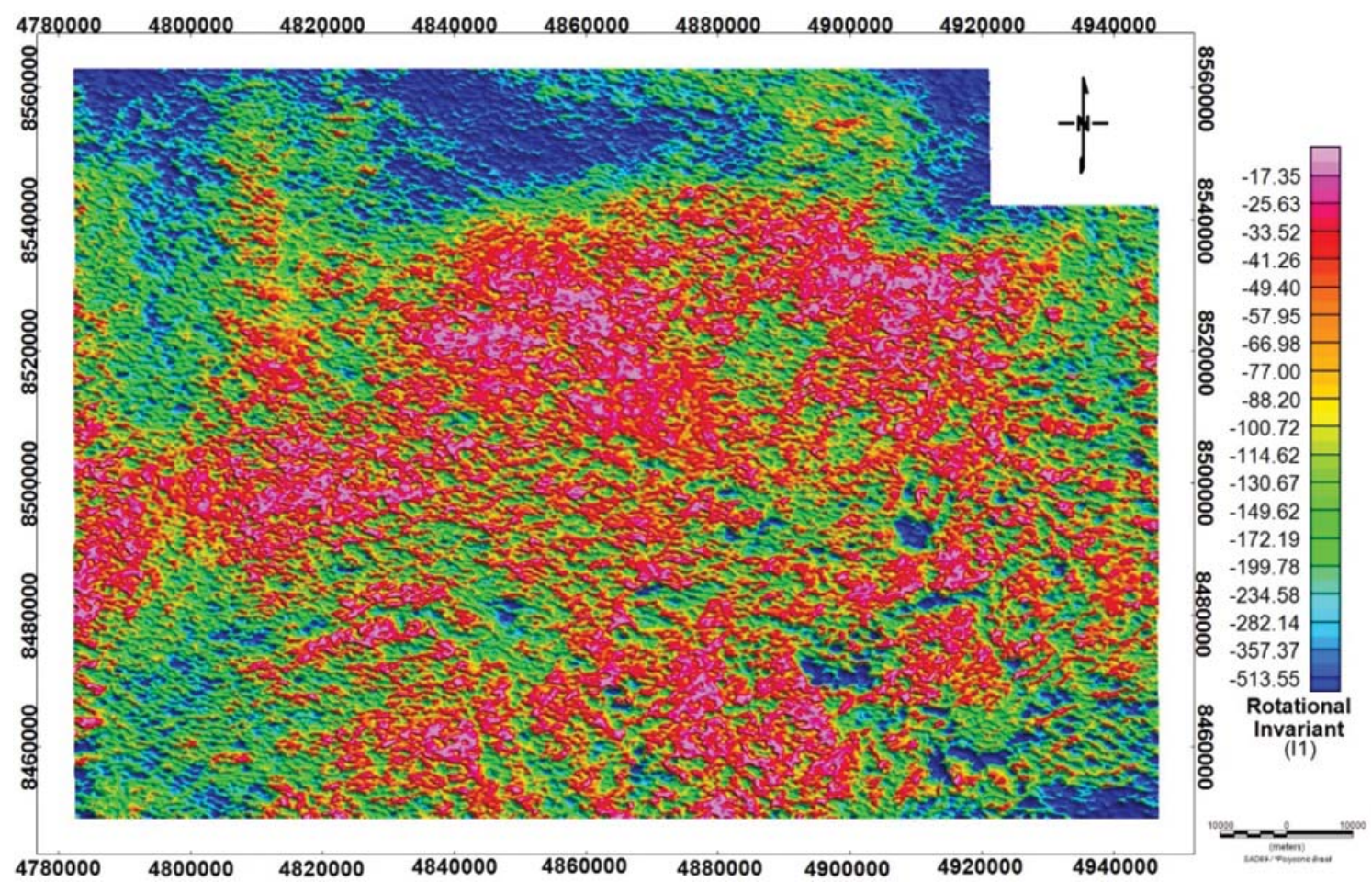

Figure 11 - Invariant 1.
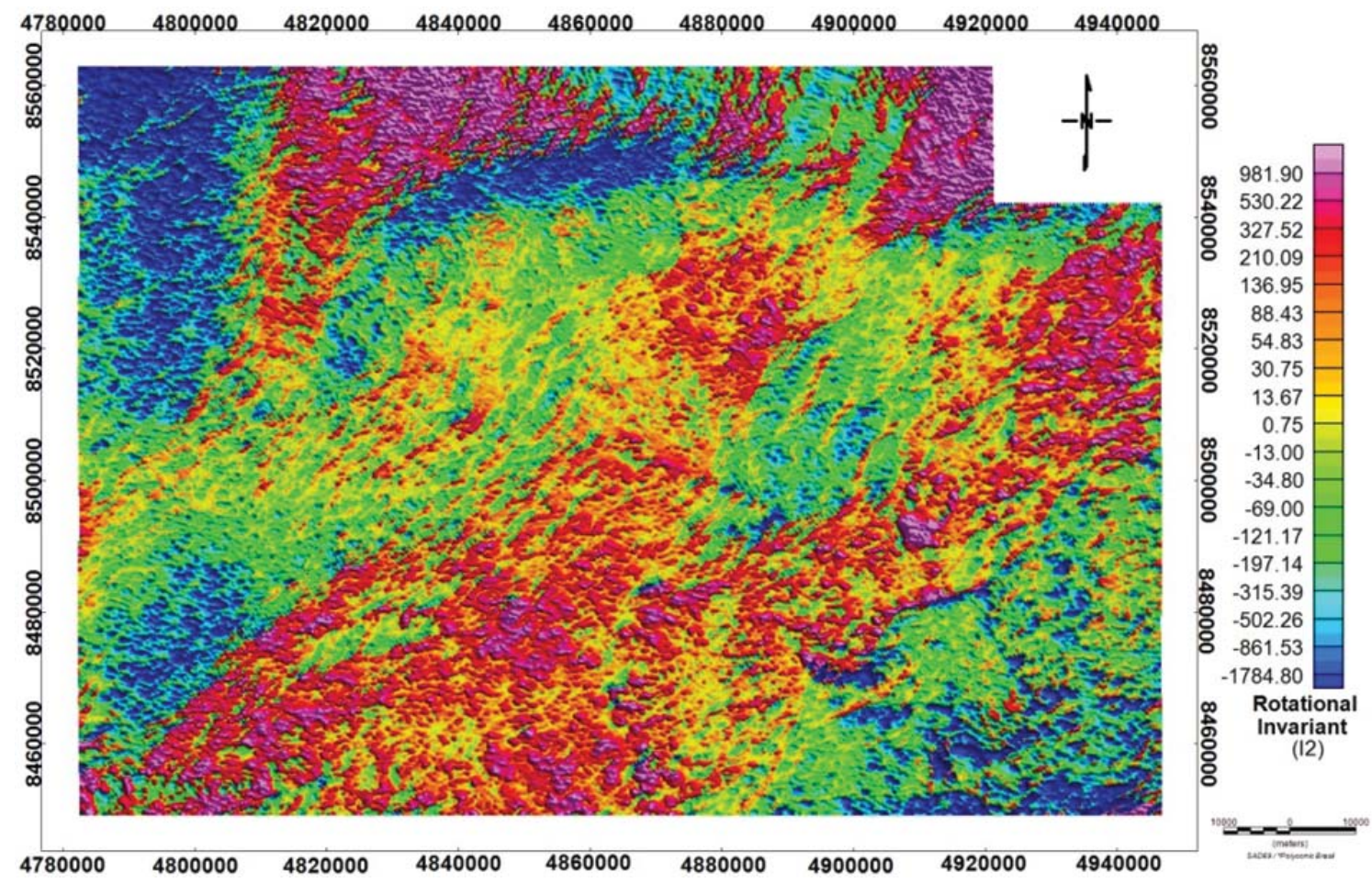

Figure 12 - Invariant 2. 
response of igneous rocks. However, these filters when applied over the total field magnetic data showed to be effective to map zones of high frequency content that can be associated to the spatial distribution of the igneous rocks. These most effective filters were: first vertical derivative (Fig. 13), tilt angle (Fig. 14), horizontal gradients (Fig. 15), that enhanced many isolated anomalies and groups of anomalies, addressing a possible area of occurrence of the igneous rock in the surveyed block. The real existence of igneous rocks depends on ground checking. Ideally, this checking shall be done with well drilling located in the mapped zones. It is worth to highlight the nonexistence of igneous rocks in the well SM-1-MT, located in the mapped area as low probability of igneous rock occurrence.

In addition to the qualitative interpretation, we have computed a total magnetic field power spectrum (Fig. 16), in order to estimate the average depth of the magnetic sources believed to be igneous rocks, and also evaluate if they represented a clear horizon or even a an extensive layer in the investigated area. As it is possible see in Figure 16, the interpreted spectrum showed three clear families of sources, the first one is very deep, that could be correlated with basement structure, one intermediate, located in the depth of $425 \mathrm{~m}$ from sensor (the average flight height was $329 \mathrm{~m}$ from terrain), that is likely to represent this layer of volcanic rock, and the third, may representing noise and some remaining superficial response. This fact also encouraged to compute the matched filter (Ravat et al., 2007) from the intermediate one (425 m) showing the extracted response from this group of sources that, can roughly, represent the spatial distribution of volcanic rocks outcropping or at a very shallow depth: 0 to 100 meters from terrain (Fig. 17).

In order to organize the results generated by qualitative interpretation methods, all results were uploaded a GIS software, aiming to proceed a qualitative zonation for "igneous rock occurrence" and generate a map of likelihood of a "well drilling intersecting igneous rocks", following the sense that conventional drilling programs, tend to avoid intersecting tick igneous sections, unless the play model considers these rocks the seals of the leads. This map is showed in Figure 17. The second objective was to generate a structural map of the area, addressing all linear features and internal structural highs and lows. This map is showed in Figure 18.

\section{D Forward modeling}

For this work we used the $2 \mathrm{D}$ modeling software called $2 \mathrm{MOD}^{\mathrm{TM}}$ that is proprietary of GMS Company. The program uses Talwanitype polygonal bodies to define the model (Talwani et al., 1959).
The main objective was to develop an Earth model that agrees with the observed seismic, gravity, magnetic and well data. Each layer in the model involves geological and geophysical assumptions: As time to depth relationships, density versus depth and density versus velocity functions (Gardner, 1974) and deep sources were incorporated into the model and tested against the geophysical input data.

The proposed methodology to achieve a consistent 2D forward modeling along the Pimenta Bueno Graben was model along the seismic line L0295-0010 Parecis, mapping the main geological sequences tied by a composite well log available along seismic profile (Fig. 19). Since the seismic profile extends just to the middle of the survey area (Fig. 1), the idea was to understand the "geologic behavior" of the layers, basement and extend the model until the end of the survey area using the extracted gravity and magnetic profiles.

The seismic section shows sequences disposed horizontally, plunging softly from west to east in the section and from northwest to southeast in the graben. This preliminary interpretation puts the interpreter of the available data in trouble, since potential fields methods are not an efficient tool to discriminate property contrasts along the vertical direction. Continuing the interpretation, it is possible to discriminate, at least, three main packs of layers (Fig. 19), and observe that the signal is lost immediately after the deeper one, around three seconds in the scale.

Assuming the above described framework we produced the first 2D model considering this loss of signal represents the interface between sedimentary layers and basement structure (Fig. 20). All the parameters used for the modeling are described in Table 1. The final model showed (Fig. 20) a very good correlation with the main features of the seismic section and a strong misfit with the extracted gravity and magnetic profiles. This fact indicated that an important content of the gravity and magnetic signals were not properly mapped, so that we applied some filters over the seismic data, in order to enhance reflectors or structures located bellow this interface, which would indicate the continuation of the sedimentary sequence without a proper mapping from seismic data.

The best result was achieved applying TECVA filter (Bulhões \& Amorim, 2005) that enhanced week reflectors in this primary "blind" portion of the section, orienting our work to model deeper basement interfaces. Beyond this, most of the magnetic depth estimations computed along this model (Fig. 20), such as, Werner Deconvolution (Werner et al., 1953), Euler Deconvolution (Thompson, 1982) and Peters half-slope technique (Peters, 1949) generated solutions deeper than this "primary basement". 


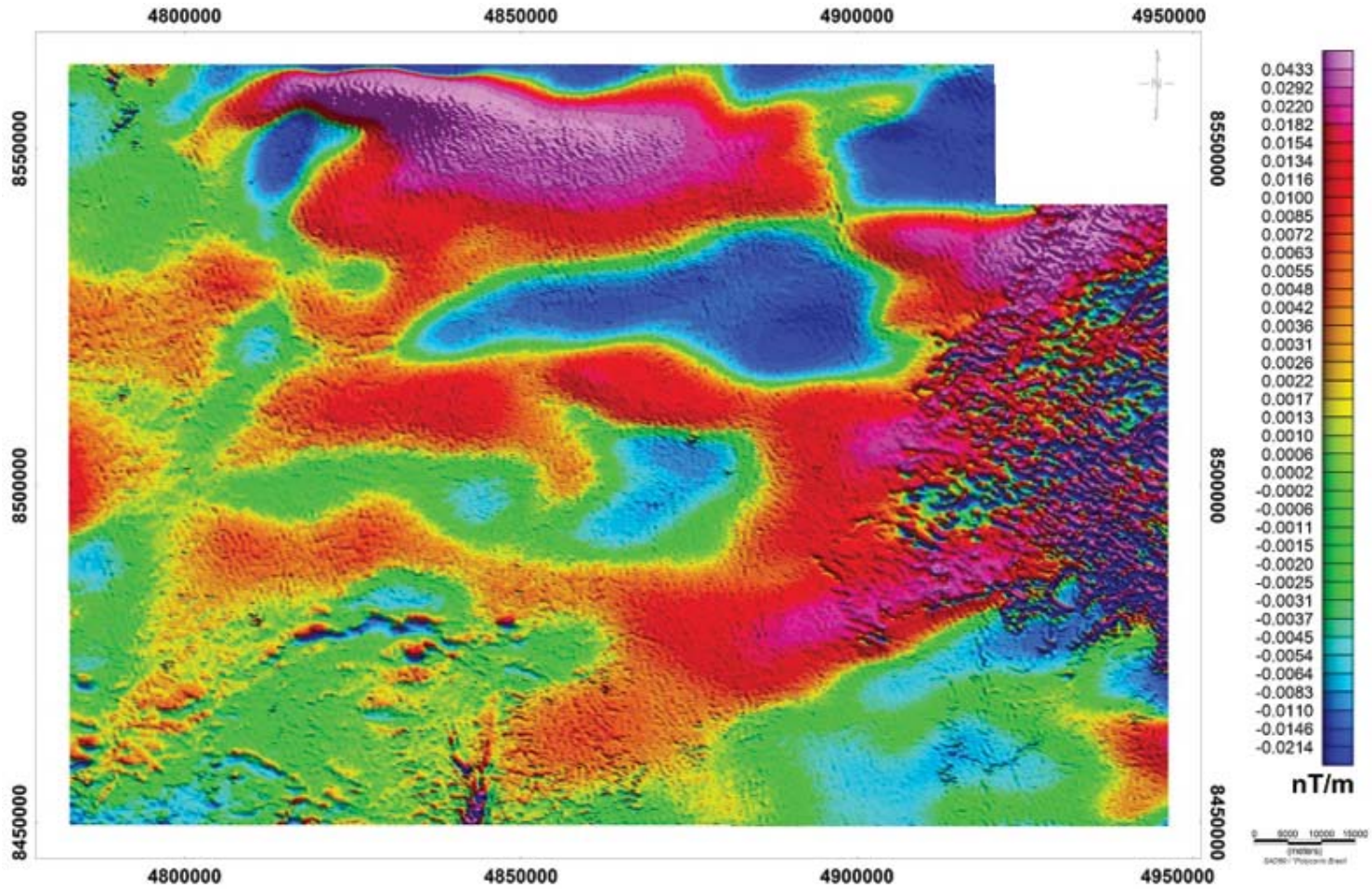

Figure 13 - First Vertical Derivative map of the Total Magnetic Intensity.

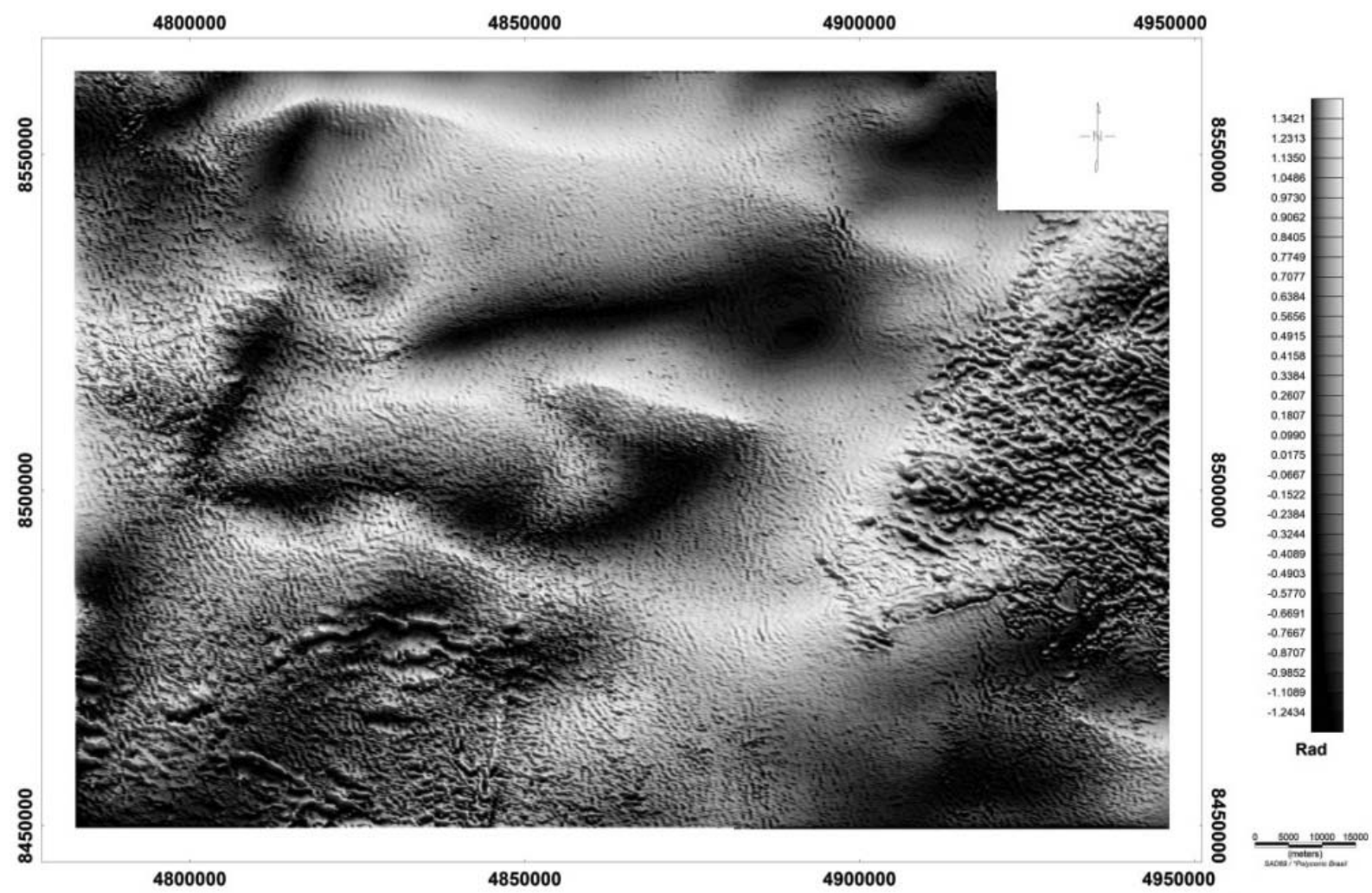

Figure 14 - Tilt Angle map of the Total Magnetic Intensity. 


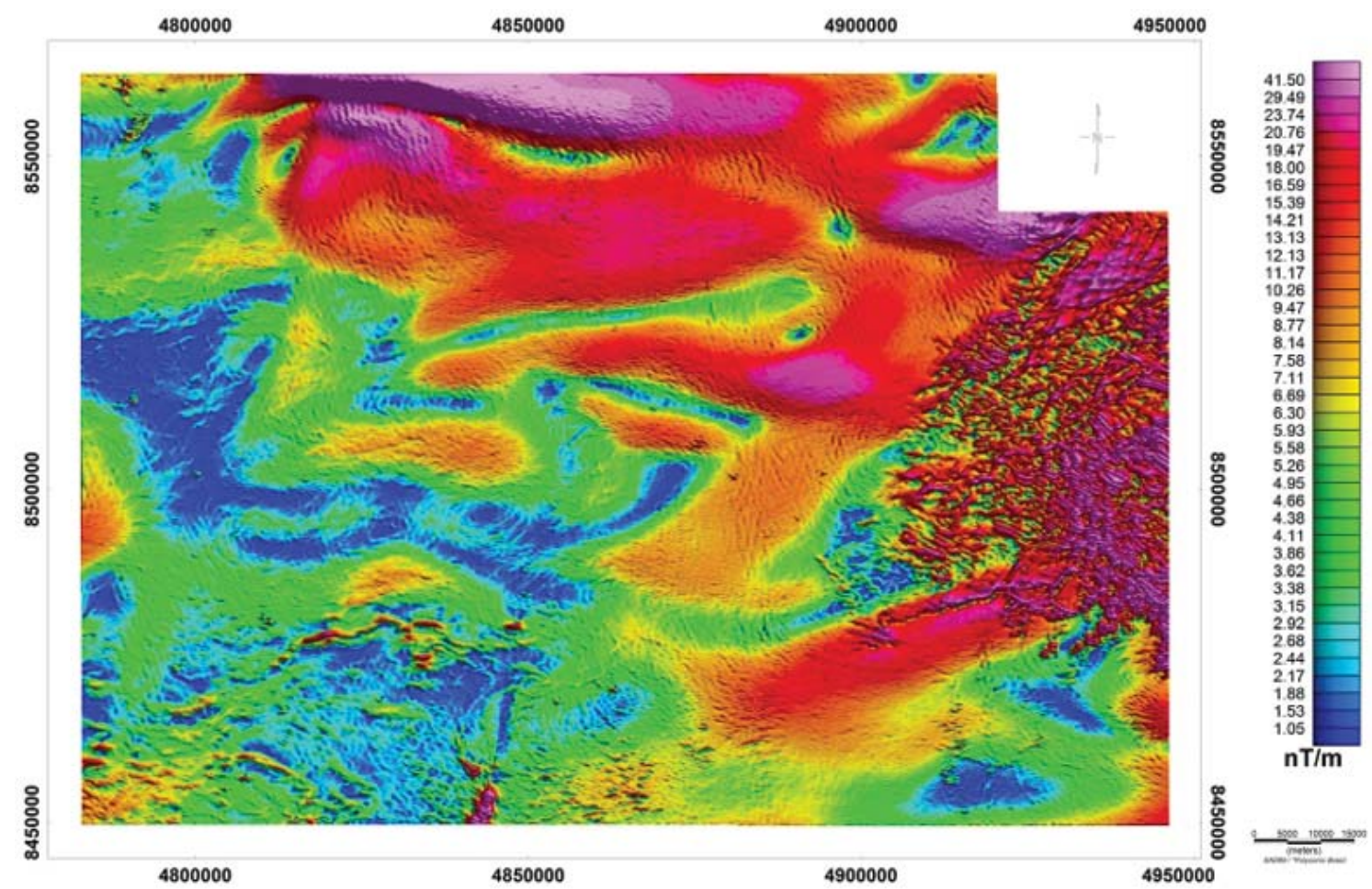

Figure 15 - Horizontal Gradient map of the Total Magnetic Intensity.

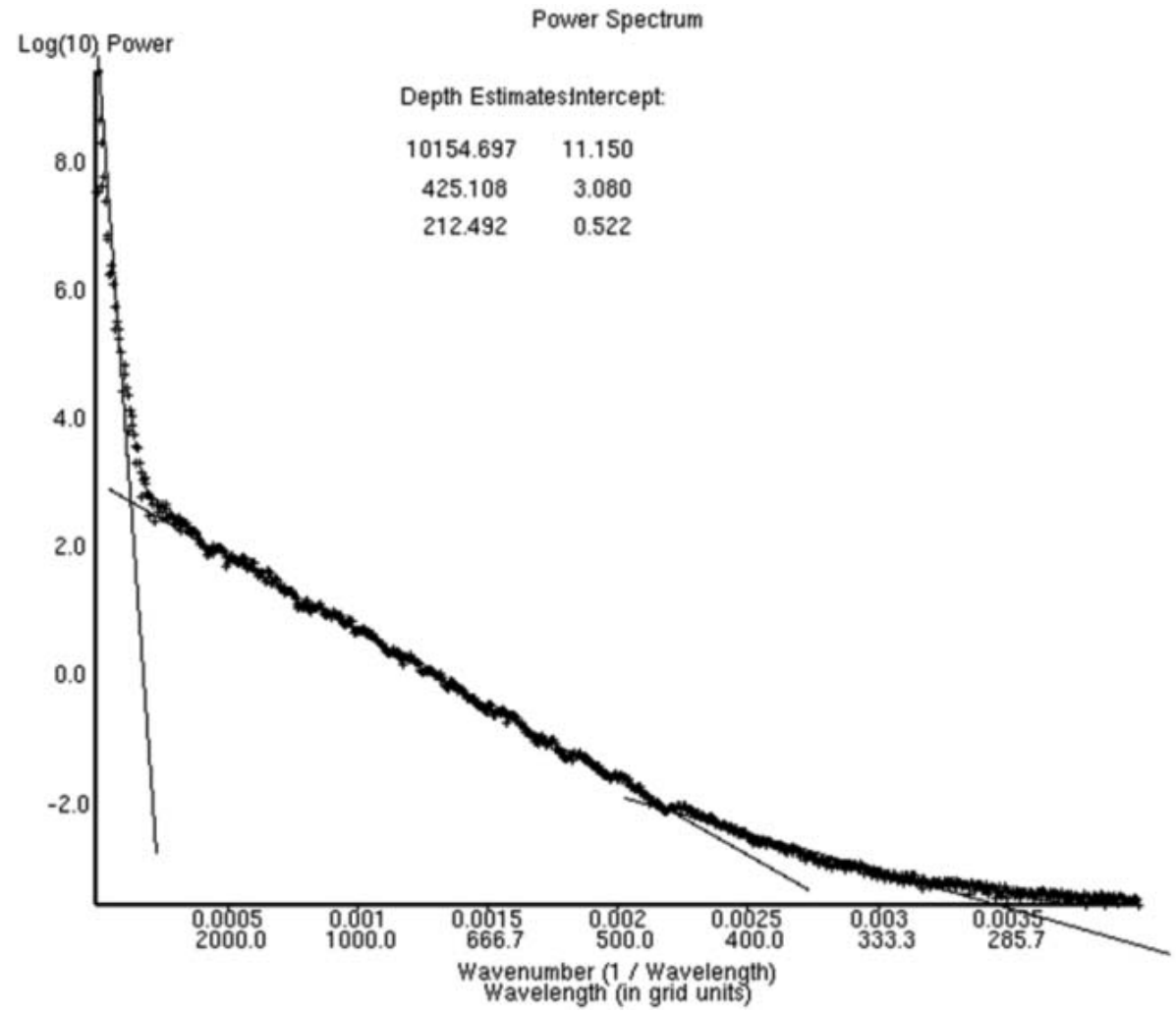

Figure 16 - Power Spectrum graphic of the total magnetic intensity map. 


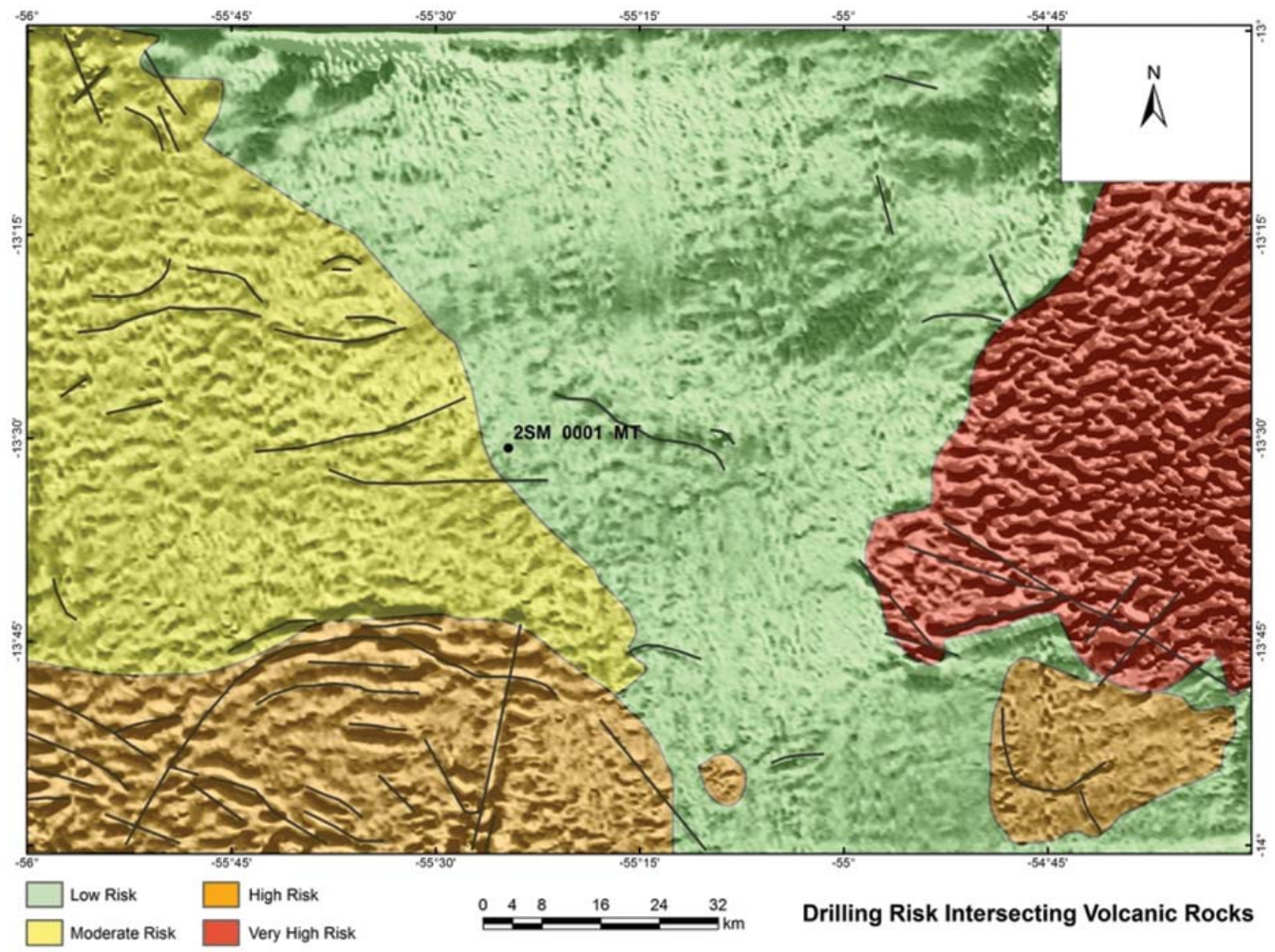

Figure 17 - Mached filter $425 \mathrm{~m}$ - Total Magnetic Intensity. The polygons represent the likelihood of wells intersecting igneous rocks in the study area. The black lines represent mapped linear features in the filter.

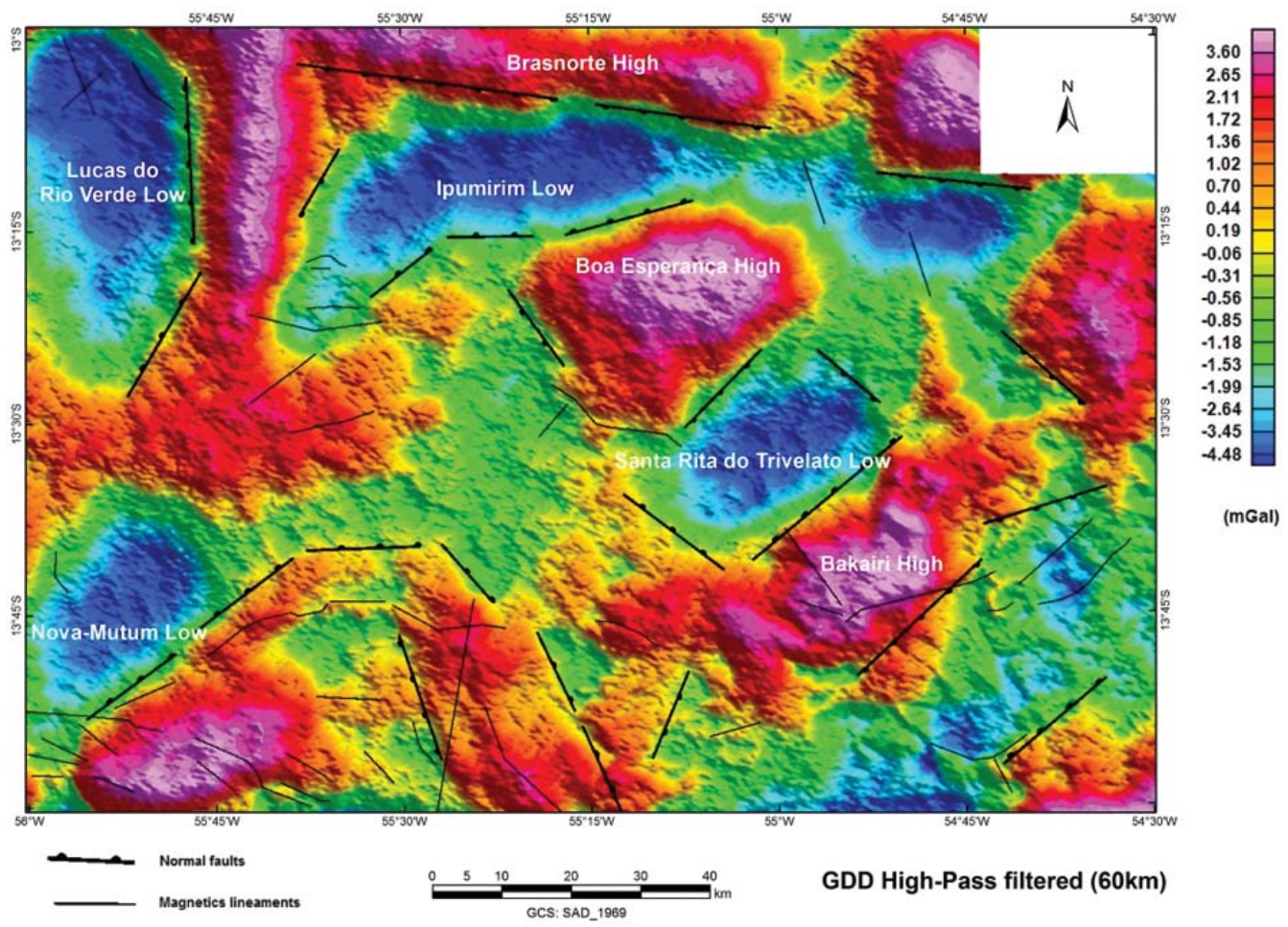

Figure 18 - Structural map of the study area over the high pass filter. 


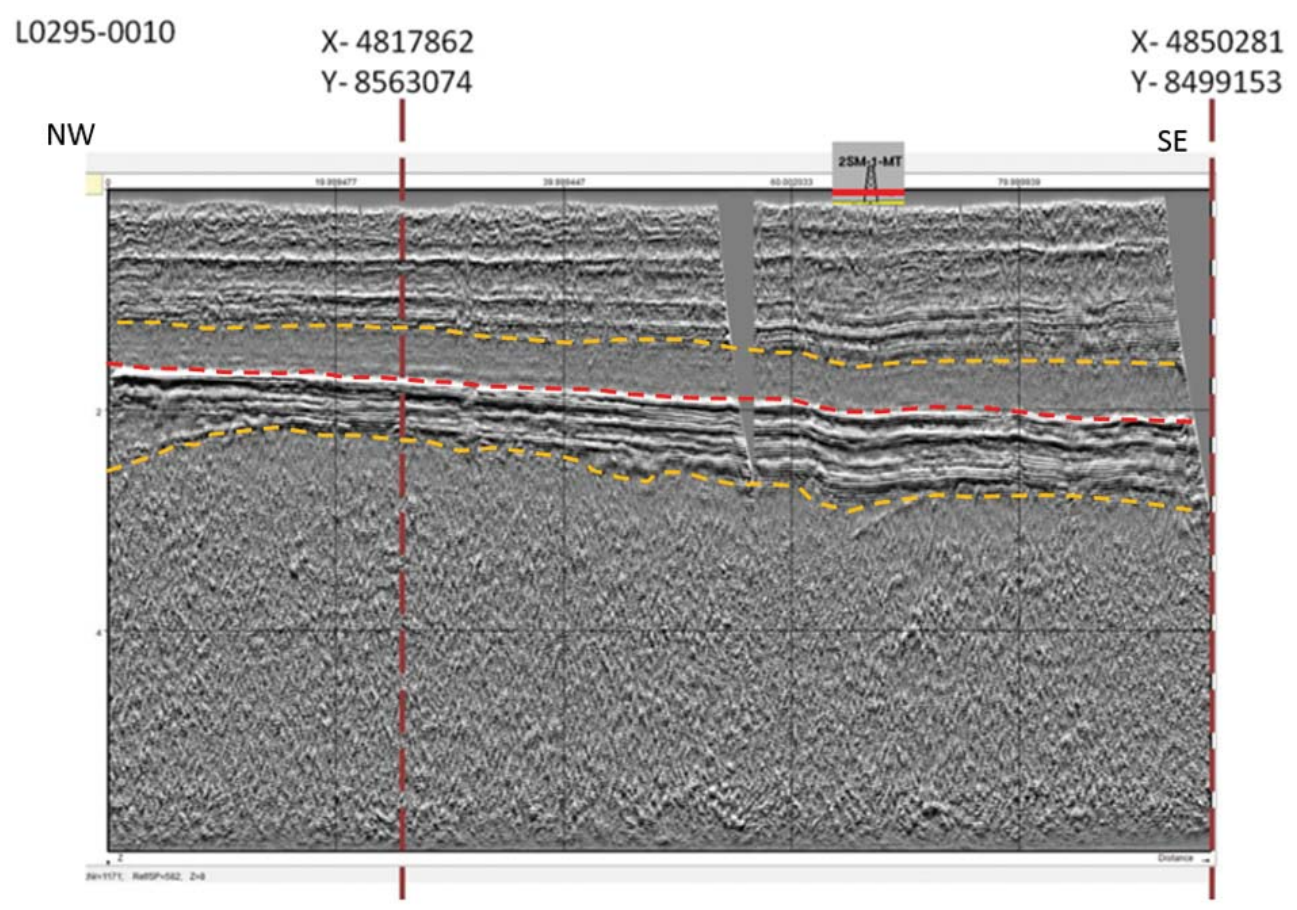

Figure 19 - Seismic Line L0295-0010 with a basic interpretation of the three main layers.

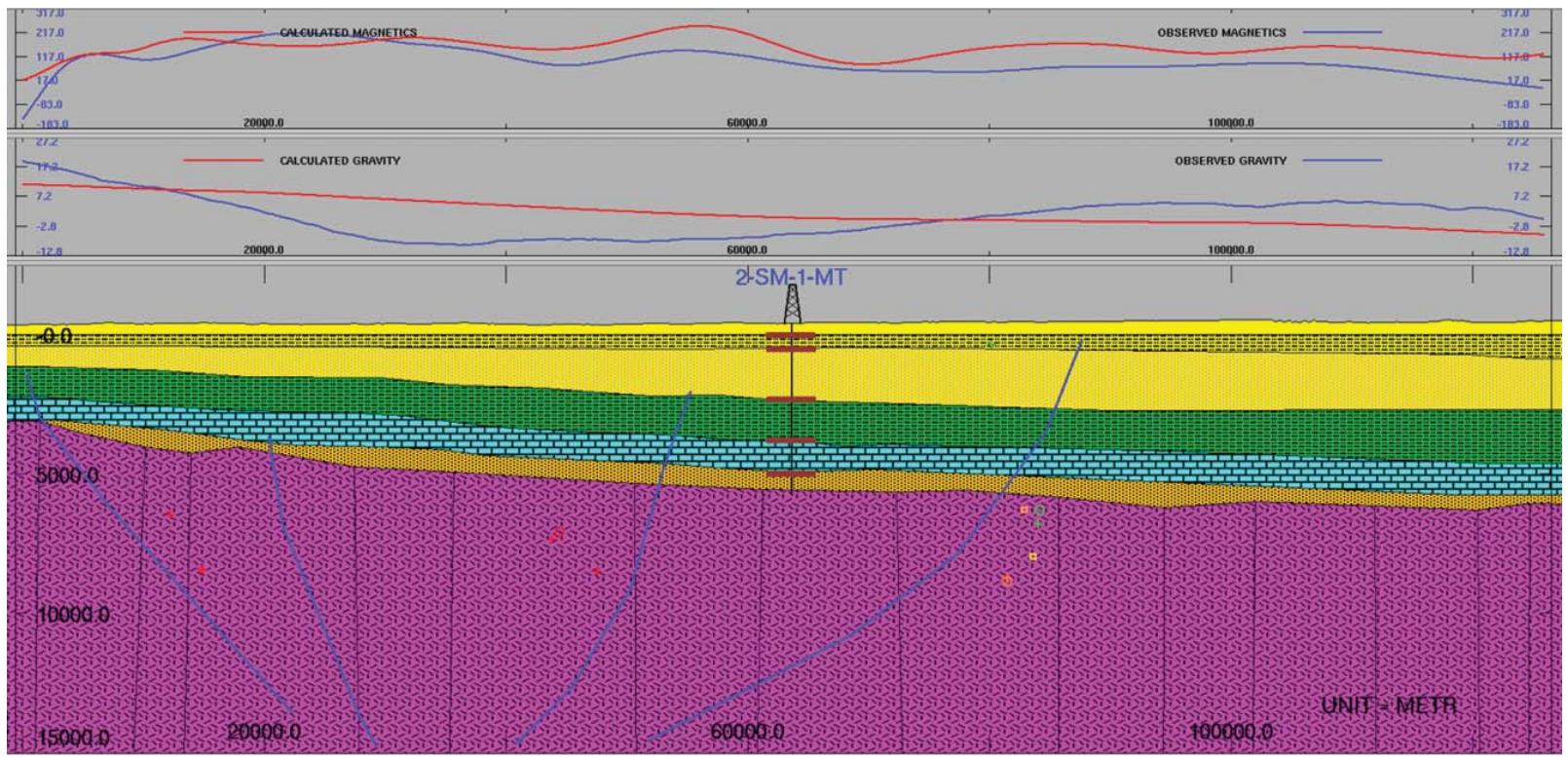

Figure 20 - First model assuming shallow basement for the line L0295-0010. Small circles, squares, and crosses represent, respectively, magnetic depth estimations calculated from Werner Deconvolution, Euler Deconvolution and Half-slope technique.

Other indications that Proterozoic basement could be deeper than this interface in the section L0295-0010 were found in the other lines acquired and processed along the basin by ANP, especially in the Colorado Graben, these lines have approximately the same dip of the L0295-0010. In those lines L0295-0008, L0295-0007, the basement was mapped around 4 seconds.

Considering this new context appointed by many different constrains, other two models (Figs. 21 and 22) were produced 
Table 1 - Values used for the modeling.

\begin{tabular}{|c|c|c|c|}
\hline Symbols & Formation & Density (g/cm3) & Susceptibility \\
\hline & sandstones & 2.50 & 0 \\
\hline & Clastic_siltites & 2.54 & 0 \\
\hline & $\begin{array}{c}\text { Clastic_low } \\
\text { energy }\end{array}$ & 2.55 & 0 \\
\hline I. & Carbonates & 2.56 & 0 \\
\hline 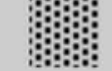 & Rift sediments & 2.58 & 0 \\
\hline & Basement & 2.70 & $1234-6549$ \\
\hline
\end{tabular}

deepening the basement interface and ticking the sedimentary Proterozoic section, in consequence, both models showed a clear improvement in the gravity and magnetic profile fitness, but the deeper one with basements interfaces achieving 13,000 meters, really adjusted to the measured profiles.

\section{DISCUSSION}

The results of the interpretation of this gravity gradiometry and magnetic survey brought many new insights about the geometry of Pimenta Bueno Graben, and mapped significant new features not reported in past publications. In fact, the tight line spacing of 500 meters, and resolution of the survey, were decisive to map innovative features in the geology of the graben, however the flight height, leveled in $760 \mathrm{~m}$ (Barometric Flight Height), damaged the final resolution of the data, even considering the advantages of recovering data from a low turbulence operations. The geometry of the Falcon Gravity Gradiometry Instrument, measuring the horizontal tensors, allows more aggressive flights, as close to the terrain, as the legislation and safety issue, ideally, from a hundred meters from terrain, that would have improved the high frequency content for both AGG and Magnetic datasets.

For the interpretation process, a conventional workflow was applied generating many enhancements from basic products: conformed gD and total magnetic intensity grid. The $2 \mathrm{D}$ models created also adjusted to these extracted profiles along the seismic section. These results mapped many structural features, defining internal compartments inside the Pimenta Bueno Graben clearly showed in the high pass filter applied over conformed gD ( $<60 \mathrm{~km}$ full wavelength).

For the modeling, other approaches using the measured tensors would be more appropriate but their geologic meanings are very complex to evaluate. Other important rule is that the models built did not follow the potential field data along the survey profiles because the available constraints did not coincide with any flight line.

The option to focus the work in the 2D modeling, despite of the availability of many tools for $3 \mathrm{D}$ inversion of gravity data aims to restrict the analyses along the location where constrained data are available: seismic section and well data. Obviously, future works can take advantage of this constrained 2D model to interpolate results for the whole survey area, but it also depends on exploratory evolution of the current works being carried by Petrobras in the remaining concessions enclosed by the survey area.

The invariants filters did not show any significant feature beyond conventional filtering, and this may happen in function of the geometry of mass distribution for what those methods were though to enhance: locate anomalous mass distribution immerse in a host rock that fits very well the mining exploration models but not so good for mapping or enhancing continuous surfaces or interfaces that represents better the mass distribution of the layers inside sedimentary basins and basement interface.

Basement depth estimations from magnetic data were not so fruitful for this scale of investigation, generating few solutions 


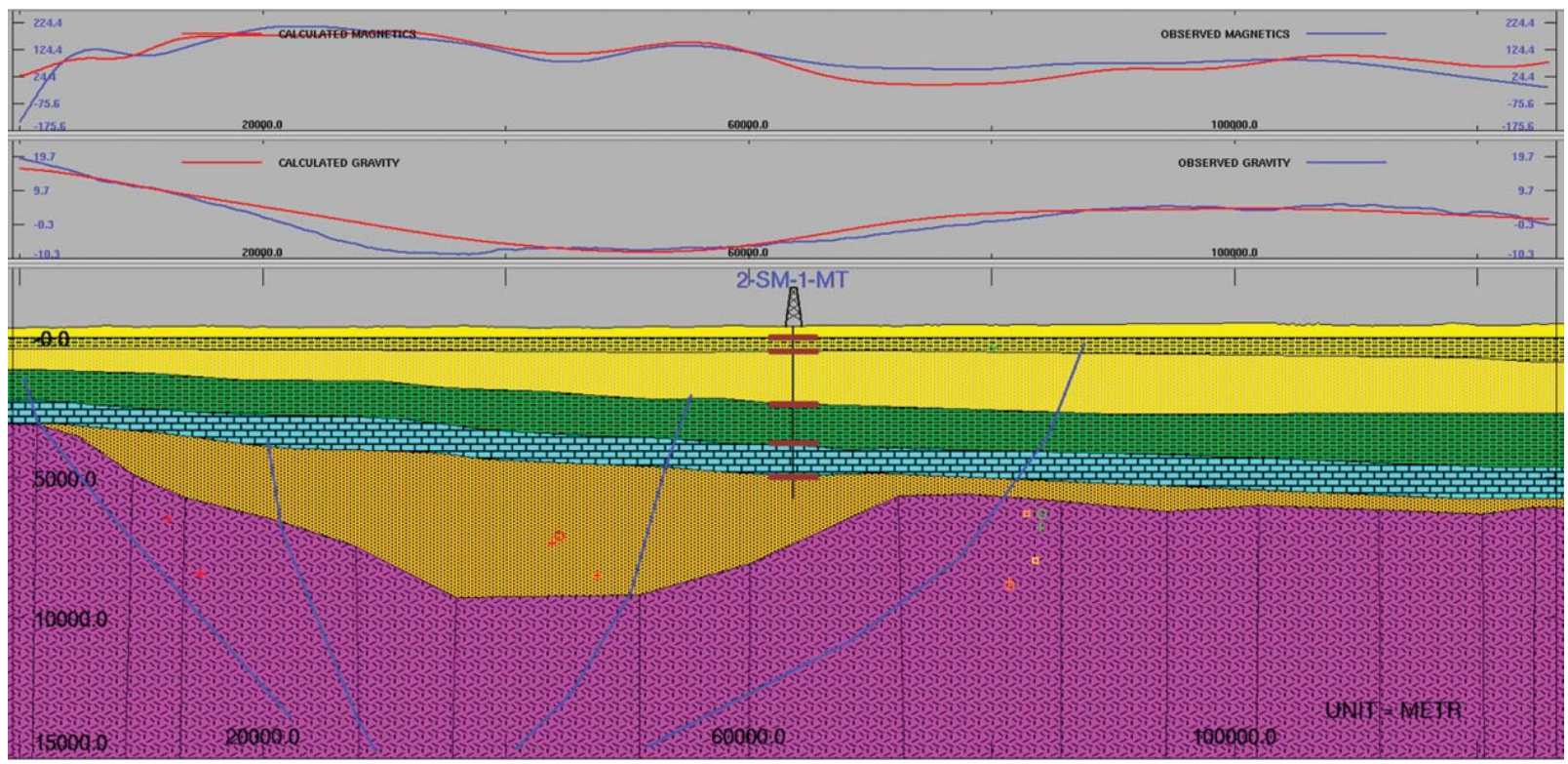

Figure 21 - Second model assuming basement with depths around 7,500 meters.

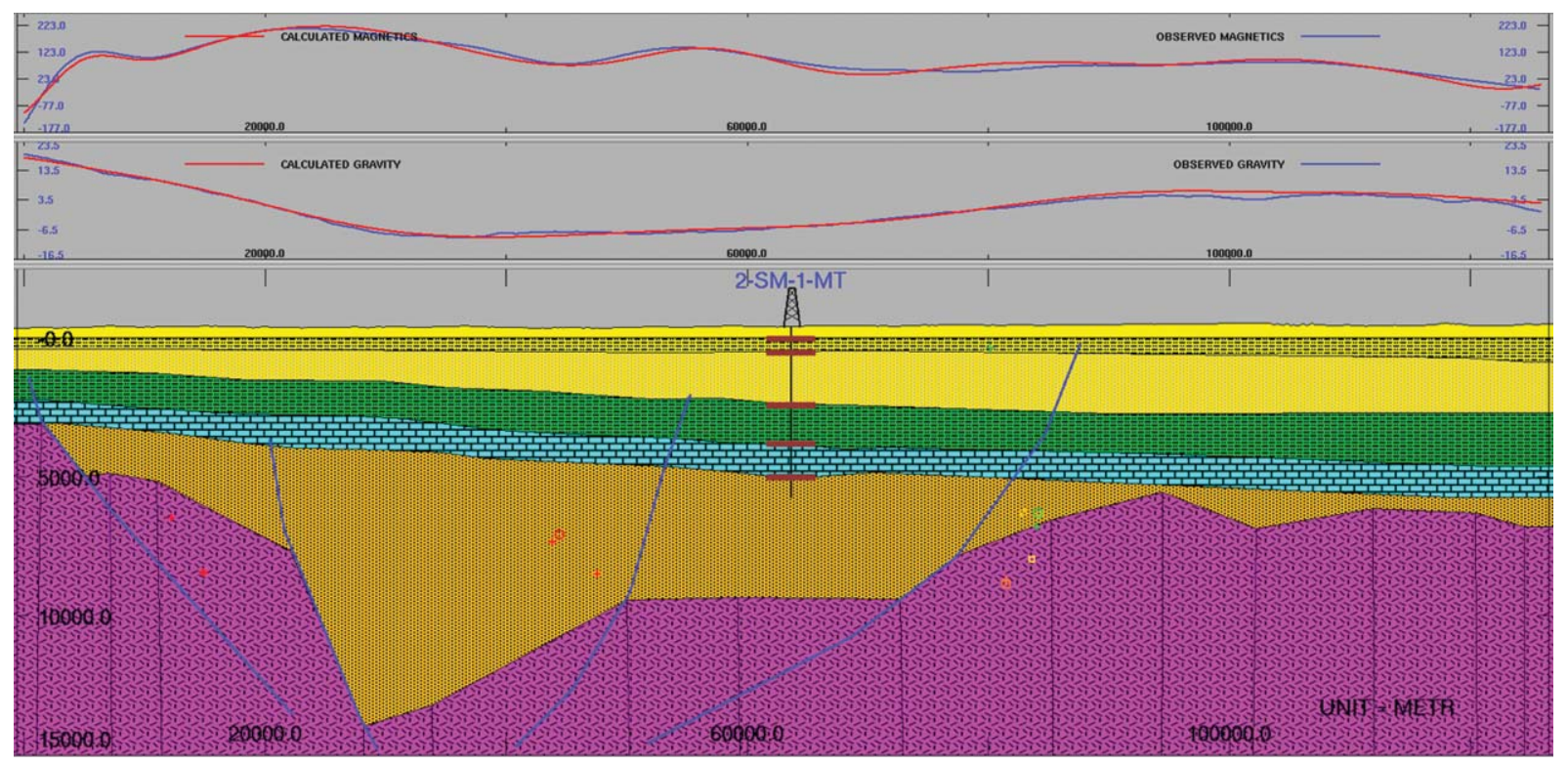

Figure 22 - Final model assuming basement interface locally reaches 13,000 meters of depth.

along tested profiles since the gradients related to the low frequency content are small and the magnetic field varies softly in the study area. This fact would indicate low contrast of magnetite content between basement rocks and the base of the sedimentary Proterozoic sequence. Despite of this, there is a clear high frequency content that may map the spatial igneous rock location. The eastern portion of the magnetic grid shows continuous and extensive group of anomalies, that seems to be a "magnetic be- havior" of shallow basalt layer. In the southern and southwestern portion of the survey, the magnetic anomalies may be related to linear folded features like extensive dikes, and in the western portion shows located anomalies that could represents small dikes or even kimberlite bodies in the project area.

The basement depth along a representative profile in the survey area and structural compartments mapped inside the Pimenta Bueno Graben are the main results of this work, generating 
new insights about the maximum depth of basin, tectonic framework, compared with the possible location of igneous rock in the project area.

\section{CONCLUSIONS}

The technical specifications applied for the airborne gravity gradiometry and magnetic survey over the southern portion of the Parecis basin allowed the achievement of many new insights about the structural framework of the Pimenta Bueno Graben. Beyond the 2D geologic model created, many other geologic features were mapped. Other reliable models along the survey area depend on the availability of new seismic surveys and new wells, that certainly will happen, with the evolution of the exploratory activity in the conceded blocks and future foment surveys sponsored by Agência Nacional do Petróleo, Gás Natural e Biocombustíveis (ANP).

\section{ACKNOWLEDGEMENTS}

Acknowledgements to CGG Brazil and CGG Multi-Physics to allow the use of the data for this work. To Albary Telles and the Geoscience department from UFRJ. A very special acknowledgement to PhD. Pedro Victor Zalán by the essential support in the seismic interpretation and geologic discussions about the genesis and sedimentary evolution of the Parecis Basin.

\section{REFERENCES}

ALMEIDA FFM. 1983. Relações Tectônicas das Rochas Alcalinas Mesozóicas da Região Meridional da Plataforma Sul-Americana. Revista Brasileira de Geociências, 13(3): 139-158.

BAHIA RBC. 2007. A Evolução Tectonossedimentar da Bacia dos Parecis - Amazônia. Universidade Federal de Ouro Preto, Ouro Preto, Minas Gerais, Brazil; Ph.D. Thesis, 149 pp.

BOGGS DB \& DRANSFIELD MH. 2004. Analysis of errors in gravity derived from the Falcon ${ }^{T M}$ airborne gravity gradiometer. In: LANE $R$ (Ed.). Airborne Gravity 2004 - Abstracts from the ASEG-PESA Airborne Gravity 2004 Workshop, Geoscience Australia Record 2004/18, 135-141. CD-ROM.

BRAGA LFS \& SIQUEIRA LP. 1995. Three-Dimensional Gravity Modelling of the Basement Topography beneath Parecis Basin, Brazil, constrained by spectral estimates of Depth to Magnetic Sources. In: Latin American Petroleum Congress, 5., Rio de Janeiro, Brazil, October 1995, $8 \mathrm{pp}$.

BULHÕES EM \& AMORIM WN de. 2005. Princípio da sismocamada elementar e sua aplicação à técnica volume de amplitudes (tecVA). In:
Intern. Cong. Braz. Geophys. Soc., 9., Expanded Abstracts, SBGf: Salvador, Bahia, Brazil, CD-ROM.

DELLA GIUSTINA MES, ALVARENGA CJS de, DARDENNE MA, SANTOS RV, DANTAS EL, PIMENTEL MM \& SIAL AN. 2005. Estratigrafia Isotópica de dois intervalos carbonáticos na borda da Bacia dos Parecis. In: Congresso Brasileiro de Geoquímica 10., Simpósio de Geoquímica dos Países do Mercosul, 2., Porto de Galinhas, Pernambuco, CD-ROM, $3 \mathrm{pp}$.

DICKINSON JL, BREWSTER JR, ROBINSON JW \& MURPHY CA. 2009. Imaging Techniques for Full Tensor Gravity Gradiometry Data. In: SAGA 2009 Biennial Technical Meeting, 11., Swaziland, Extended Abstracts, pp. 84-88.

DRANSFIELD MH. 2010. Conforming Falcon gravity and the global gravity anomaly. Geophysical Prospecting, 58: 469-483.

DRANSFIELD MH \& LEE JB. 2004. The FALCON ${ }^{\text {TM }}$ airborne gravity gradiometer survey systems. In: LANE R (Ed.). Airborne Gravity 2004 Abstracts from the ASEG-PESA Airborne Gravity 2004 Workshop, Geoscience Australia Record 2004/18, pp. 15-19.

DRANSFIELD M \& ZENG Y. 2009. Airborne gravity gradiometry: Terrain corrections and elevation error. Geophysics, 74(5): 137-142, doi: 10.1190/1.3170688.

FIGUEIREDO MF, BABISNKI M, ALVARENGA CJS de, PINHO FEC \& SIMON CM. 2006. Chemostratigraphy (C, 0 and Sr) of Ediacaran postglacial carbonates of Paraguay Belt, Mato Grosso, Brazil. In: South American Symposium on Isotope Geology, Uruguay.

GARDNER GHF, GARDNER LW \& GREGORY AR. 1974. Formation velocity and density - the diagnostic basics for stratigraphic traps. Geophysics, 39: 770-780.

HAESER B. 2013. Brazil $12^{\text {th }}$ Round: Oil \& Gas Bidding Rounds Parecis Basin patterns. ANP webpage, Brazil. Available on:

$<$ http://www.brasil-rounds.gov.br/arquivos/Seminarios_R12/apresentacao/Parecis_R12_English.pdf>. Access on: December 15, 2013.

LEE JB. 2001. FALCON Gravity Gradiometer Technology. Exploration Geophysics, 32: 75-79.

LEE JB, LIU G, ROSE M, DRANSFIELD M, MAHANTA A, CHRISTENSEN A \& STONE P. 2001. High resolution gravity surveys from a fixed wing aircraft. In: Geoscienceand Remote Sensing Symposium, 2001. IGARSS '01. IEEE 2001 International, 3: 1327-1331.

NOGUEIRA ACR, RICCOMINI C, SIAL AN, MOURA CAV, TRINDADE RIF \& FAIRCHILD TR. 2007. Carbon and Strontium isotope fluctuations and paleoceanographic changes in the late Neoproterozoic Araras carbonate platform, southern Amazon Craton, Brazil. Chemical Geology, 237: 168-190.

PETERS LJ. 1949. The direct approach to magnetic interpretation and its practical application. Geophysics, 14: 290-320. 
RAVAT D, PIGNATELLI A, NICOLOSI I \& CHIAPPINI M. 2007. A study of spectral methods of estimating the depth to the bottom of magnetic sources from near-surface magnetic anomaly data. Geophys. J. Int., 169: 421-434.

RICCOMINI C, NOGUEIRA ACR \& SIAL AN. 2007. Carbon and oxygen isotope geochemistry of Ediacaran outer platform carbonates, Paraguay Belt, central Brazil. Anais da Academia Brasileira de Ciências, 79(3): 519-527.

SIQUEIRA LP \& TEIXEIRA LB. 1993. Bacia dos Parecis: nova fronteira exploratória da Petrobras. In: Intern. Congr. Braz. Geophys. Soc., 3., Expanded Abstracts, SBGf: Rio de Janeiro, RJ, Brazil, pp. 168-170.
TALWANI M, WORZEL JL \& LANDISMAN M. 1959. Rapid gravity computations for two-dimensional bodies with application to the Mendocino submarine fracture zone. J. Geophys. Res., 64(1): 49-59.

THOMPSONDT. 1982. EULDPH: A new technique for making computerassisted depth estimates from magnetic data. Geophysics, 47: 31-37.

WERNER H, WAPNER S \& BRUELL J. 1953. Experiments on sensorytonic field theory of perception: VI. The effect of position of head, eyes, and of object on the position of the apparent median plane. J. Exp. Psychol., 46: 293-299.

\section{NOTES ABOUT THE AUTHORS}

Alan de Souza Cunha is a Petroleum Engineer and Physicist who has been working with Geophysics since 2006. Has worked for two years with mining exploration at Omega-Gama Mineração with gold and diamond exploration. In 2008 moved to Fugro Airborne Surveys as a field Geophysicist and in 2009 was transferred to the office to support the technical marketing department. Was appointed marketing manager for Fugro Gravity and Magnetic Services, company based in Houston in 2012. Since the acquisition of the geoscience division of Fugro by CGG in early 2013 has been in the position of Business Development Manager supporting the CGG activities in the Latin America Geomarket.

Fabio Andre Perosi is Associate Professor of Geophysics at undergraduate and graduate degrees in the Department of Geology, working in the LAGEP (Laboratory of Geophysics and Petrophysics) at Universidade Federal do Rio de Janeiro (UFRJ). Main research interests are Seismic and Gravimetric Methods, Well Logging and Petrophysics. Undergraduation in Physics (1997) from Universidade Federal do Rio Grande do Sul (UFRGS), M.Sc. (2000) and Ph.D. (2006) in Geophysics from Universidade de São Paulo (USP) and a long-term internship (dec/2003-jul/2004) at U.S. Geological Survey, in Menlo Park, CA. Also has an interest in Geosciences and Physics Education.

Luiz Fernando Braga is an exploration geophysicist with nearly 18 years of petroleum industry experience, and over 35 years in the Earth Sciences. Has been involved in acquisition, processing and interpretation of almost all geophysical methods applied to petroleum exploration, with major experience with Potential Fields Methods integrated to Seismic works. Has worked for many years in Geosciences Research. Along his career, has occupied leadership positions in various companies: HighSense, CGG-Geomag, Fugro VP of Global Business Development and as CGG VP and Geomarket Director for Latin America. At present leads R\&D and Business Development for Seabed Geosolutions and Invision Geophysics.

Leandro Barros Adriano graduated in 2006 and Master's degree in 2014 at Universidade do Estado do Rio de Janeiro (UERJ). He is an exploration geologist with almost 10 years experience working in several sedimentary basins in South America. Worked in acquisition, processing and interpretation of potential fields data and seismic interpretation. In South America, participated in projects in Solimões, Parnaíba, Paraná, Campos, Santos, Amazonas and all the sedimentary basins in the Brazilian Equatorial Margin. From 2006 to present, worked for different geophysical survey companies, including Fugro Lasa, IPEX, and CGG Multi-Physics. In 2015 has entered in the doctorate degree program of Universidade do Estado do Rio de Janeiro (UERJ).

Marlon Cabrera Hidalgo-Gato is bachelors of Geophysics at the Universidade de São Paulo (2010). Geophysicist at CGG with 3 years experiences in electromagnetics, resistivity, induced polarization and potential methods acquisition and interpretation. Now working in an R\&D project in the Brazilian Equatorial Margin.

Victor Pereira do Couto is geophysicist graduated at Universidade Federal Fluminense (UFF) and initiated his career in magnetotelluric data acquisition at Strataimage. After that, worked in quality control and processing of aeromagnetic, gravity and gammaspectrometry at CGG Multi-Physics. Also participated in R\&D projects in CGG Multi-Physics.

Daniel Santos da Silva is GIS technician with 9 years of experience. Began his career in 2004 at LABGIS - Laboratório de Geotecnologias, Faculdade de Geologia, Universidade do Estado do Rio de Janeiro (UERJ), working on creation and management of geodatabases, elaboration of thematic maps and final layouts. Hired by Fugro Airborne Surveys in 2009, worked in the field as processor of magnetic and gravimetric data. Currently, works at CGG Multi-Physics as GIS Technologist in a R\&D project. 